\title{
Paylaşımlı Elektrik Enerjisi Depolama Sisteminin Kullanımına Dayanan Bir Enerji Yönetimi Yaklaşımı
}

\author{
Akın Taşcıkaraoğlu ${ }^{1 *}$, Ozan Erdinç ${ }^{2}$ \\ ${ }^{1}$ Muğla Sıtkı Koçman Üniversitesi, Mühendislik Fakültesi, Elektrik Elektronik Mühendisliği Bölümü, Muğla, Türkiye (ORCID: 0000-0001-8696-6516) \\ ${ }^{2}$ Yıldız Teknik Üniversitesi, Elektrik Elektronik Fakültesi, Elektrik Mühendisliği Bölümü, İstanbul, Türkiye (ORCID: 0000-0003-0635-9033)
}

(İlk Geliş Tarihi 8 Haziran 2019 ve Kabul Tarihi 16 Temmuz 2019)

(DOI: 10.31590 /ejosat.574062)

ATIF/REFERENCE: Taşcıkaraoğlu, A. \& Erdinç, O. (2019). Paylaşımlı Elektrik Enerjisi Depolama Sisteminin Kullanımına Dayanan Bir Enerji Yönetimi Yaklaşımı. European Journal of Science and Technology, (16), 589-604.

\begin{abstract}
$\ddot{\mathbf{O z}}$
$\mathrm{Bu}$ çalışmada, bir paylaşımlı elektrik enerjisi depolama sistemi kullanan ve aynı bölge içerisinde yer alan belli bir sayıdaki evsel tüketicinin toplam enerji maliyetini en aza indirebilmek ve bu evlerin bağlı olduğu dağıtım şebekesindeki pik yük talebini azaltabilmek amacıyla bir tahmin algoritmasına dayanan bir enerji yönetimi yaklaşımı önerilmektedir. Önerilen yöntem, farklı güçlerde fotovoltaik (PV) panellere sahip olan evlere ait elektrik üretimi ve tüketimi miktarlarını, bu değerlere ait farklı zaman ölçeklerindeki tahminleri ve bir gerçek zamanlı fiyatlama elektrik tarifesine ait değişken fiyatları dikkate alarak, evler tarafından üretilen elektrik enerjisinden en yüksek seviyede faydalanmayı hedeflemektedir. Bu amaçla, her bir eve ait üretim, öncelikle evin kendisinin tüketimini karşılamak amacıyla kullanılmaktadır. İhtiyaç fazlası üretimin mevcut olması durumunda ise üretilen enerji belirtilen değişkenler dikkate alınarak bölge içerisindeki diğer evlerin tüketimi için kullanılmakta, paylaşımlı depolama sisteminde depolanmakta veya şebekeye satılmaktadır. Önerilen yaklaşımına göre evler, şebekeye veya bölgedeki diğer evlere sağladıkları enerji miktarı oranında enerji kredileri kazanmaktadırlar ve bu kredilere karşılık gelecek miktarda enerjiyi paylaşımlı enerji depolama sisteminden, özellikle elektrik satın alma fiyatının yüksek olduğu zaman dilimlerinde kullanarak önemli bir maddi kazanç elde etmektedirler. Belirli bir sayıda evsel tüketiciye ait gerçek yük talebi ve PV güç üretimi verileri kullanılarak yapılan benzetim çalışmalarında, paylaşımlı enerji depolama sisteminin var olmadığı durumda elde edilen sonuçlar ile ve depolama sisteminin var olduğu ancak ilgili tahmin değerlerinin göz önüne alınmadığı durumda elde edilen sonuçlar ile karşılaştırmalar yapılmıştır. Belirtilen karşılaştırmalar, önerilen paylaşımlı enerji depolama sistemi ve tahmin algoritması kullanımına dayanan enerji yönetimi yaklaşımının son kullanıcı açısından enerji maliyetini azaltmakta ve dağıtım sistemi işletmecisi açısından pik yük talebini sınırlamakta etkili olduğunu göstermiştir.
\end{abstract}

Anahtar Kelimeler: Enerji yönetimi, fotovoltaik güç tahmini, fotovoltaik sistemler, paylaşımlı enerji depolama sistemi, yük talebi tahmini.

\section{An Energy Management Approach Based on the Use of Shared Electrical Energy Storage System}

\begin{abstract}
In this study, an energy management approach based on a forecasting algorithm is proposed in order to minimize the total energy cost of a certain number of residential consumers using a shared electrical energy storage system and located in the same area, and to reduce the peak load demand in the distribution network to which these houses are connected. The proposed method aims to utilize the electricity produced by the houses at the highest level by taking into account the amounts of electricity production and consumption of

\footnotetext{
* Corresponding Author: Muğla Sitkı Koçman Üniversitesi, Mühendislik Fakültesi, Elektrik Elektronik Mühendisliği Bölümü, Muğla, Türkiye, ORCID: 0000-0001-8696-6516, akintascikaraoglu@mu.edu.tr
} 
houses with photovoltaic (PV) panels of different powers, forecasts of these values at different time scales and variable prices of a realtime pricing electricity tariff. For this purpose, the production of each house is used primarily to meet the consumption of the house itself. In case of surplus production, the produced energy is used for the consumption of other houses in the area, stored in the shared storage system or sold to the network by taking the mentioned variables into account. According to the proposed approach, houses earn energy credits in proportion to the amount of energy they provide to the grid or other houses in the area, and they obtain a significant financial gain by using the corresponding amount of energy from the shared energy storage system, especially in the periods of high electricity purchase price. In the simulation studies carried out by using real load demand and PV power production data for a certain number of residential consumers, the comparisons are performed with the results obtained in the absence of a shared energy storage system and the results obtained in case the storage system exists but the relevant forecast values are not taken into consideration. These comparisons have shown that the proposed energy management approach based on the use of shared energy storage system and forecasting algorithm is effective in reducing the energy cost for the end user and limiting the peak load demand for the distribution system operator.

Keywords: Energy management, load demand forecasting, photovoltaic power forecasting, photovoltaic systems, shared energy storage system.

\section{Terimler Dizisi}

A. Küme ve İndisler

$e(E) \quad$ ev indisi (kümesi).

$z(Z) \quad$ zaman indisi (kümesi).

B. Parametreler

$D V^{B A T}$

$E^{\text {kredi,ilk }}$

$E_{e}^{\text {kredi }}$

$L^{B A T, \text { desarj }}$

$L^{B A T, \text { sarj }}$

$P_{e, z}^{P V}$ kullanilan

$P_{e, z}^{P V \text { uretim }}$

$S$

SOE $E^{B A T, i l k}$

$S O E^{B A T, m a k s}$

$S O E^{B A T, \min }$

$S V^{B A T}$

$Y_{e, z}$

$Z^{D R \_b a s l a n g i c}$

$Z^{D R_{-} b i t i s}$

$\lambda_{z}^{\text {alinan }}$

$\lambda_{z}^{\text {satilan }}$

$\Delta Z$

\section{Değişkenler}

$E_{e, z}^{k r e d i}$

$e$

$P_{e z}^{\text {alinan, BAT }}$

$P_{e, z}$

$P_{e, Z}^{\text {alinan }, S}$

$P_{e, z}^{\text {alinan }, T}$

$P_{e, z}$

$P_{e, Z}^{\text {alinan }, Y}$

$P_{e, Z}^{B A T}$

$P_{Z}^{B A T, \text { desarj }}$

$P_{Z}^{B A T \rightarrow K}$

$P_{Z}^{B A T, s a r j}$

$P_{Z}^{B A T \rightarrow T R}$

$P_{Z}^{S \rightarrow T R}$

$P_{Z}^{K \rightarrow B A T}$ paylaşımlı bataryanın deşarj verimi.

$e$ evinin başlangıç anındaki kredisi [kWh].

sistem operatörü tarafindan belirlenen $e$ evine ait kredi limiti $[\mathrm{kWh}]$.

paylaşımlı bataryanın deşarj hızı limiti [kW].

paylaşımlı bataryanın şarj hızı limiti $[\mathrm{kW}]$.

$z$ periyodunda iç tüketimi karşılamak için kullanılan $e$ evine ait $\mathrm{PV}$ gücünün miktarı [kW].

$z$ periyodunda $e$ evinin $\mathrm{PV}$ sisteminin mevcut gücü [kW].

yeterince büyük pozitif bir sabit.

paylaşımlı bataryanın başlangıç anındaki şarjlılık durumu [kWh].

paylaşımlı bataryanın en yüksek şarjlılık durumu [kWh].

paylaşımlı bataryanın en düşük şarjlılık durumu [kWh].

paylaşımlı bataryanın şarj verimi.

$z$ periyodunda $e$ evine ait esnek olmayan yük $[\mathrm{kW}]$.

talep cevabı uygulamasının başlangıç zamanı.

talep cevabı uygulamasının bitiş zamanı.

enerjinin satın alındığı fiyat [TL/MWh]

enerjinin satıldığı fiyat [TL/MWh]

zaman aralığı süresi [h].

$z$ periyodunda $e$ evinin elde ettiği toplam kredi [kWh].

Gauss gürültüsü.

$z$ periyodunda $e$ evinin paylaşımlı bataryadan çektiği toplam gücün miktarı [kW].

$z$ periyodunda $e$ evinin şebekeden çektiği toplam gücün miktarı [kW].

$z$ periyodunda $e$ evinin çektiği toplam güç [kW].

$z$ periyodunda $e$ evinin yerel komşu alan ağından çektiği gücün miktarı $[\mathrm{kW}]$.

$z$ periyodunda $e$ evinin paylaşımlı bataryadan çektiği toplam gücün miktarı [kW].

$z$ periyodunda paylaşımlı bataryanın deşarj gücü $[\mathrm{kW}]$.

$z$ periyodunda komşu alan ağı sistemine verilen paylaşımlı batarya gücünün miktarı [kW].

$z$ periyodunda paylaşımlı bataryanın şarj gücü [kW].

$z$ periyodunda trafo aracılığıyla şebekeye verilen paylaşımlı batarya gücünün miktarı [kW].

$z$ periyodunda trafo aracılığıyla şebekeden komşu alan ağına ve paylaşımlı bataryaya akan toplam güç [kW].

$z$ periyodunda paylaşımlı bataryaya verilen komşu alan ağı ihtiyaç fazlası gücün miktarı [kW]. 


$P_{z}^{K \rightarrow T R}$
$P_{h, t}^{\text {satilan,BAT }}$
$P_{e, z}^{\text {satilan }, S}$
$P_{e, z}^{\text {satilan }, Z}$
$P_{e, z}^{\text {Satilan }, Y}$
$P_{z}^{T R \rightarrow B A T}$
$P_{z}^{T R \rightarrow K}$
$P_{z}^{T R \rightarrow S}$
$S O E_{z}^{B A T}$
$u_{z}^{1}$
$u_{z}^{2}$
$u_{z}^{3}$
$u_{z}^{4}$
$X$
$y$

$z$ periyodunda komşu alan ağından trafoya akan toplam güç [kW].

$z$ periyodunda $e$ evinin paylaşımlı bataryaya verdiği toplam güç [kW].

$z$ periyodunda $e$ evinin $\mathrm{OBN}$ 'ye verdiği şebekeye geri akan güç miktarı [kW].

$z$ periyodunda $e$ evinin OBN'ye verdiği toplam güç [kW].

$z$ periyodunda $e$ evinin OBN'ye verdiği komşu alan ağı içerisinde yerel olarak kullanılan gücün miktarı [kW].

$z$ periyodunda trafodan paylaşımlı bataryaya akan toplam güç [kW].

$z$ periyodunda trafodan komşu alan ağına akan toplam güç [kW].

$z$ periyodunda komşu alan ağından ve paylaşımlı bataryadan trafo aracılığıyla şebekeye akan toplam güç [kW].

$z$ periyodunda paylaşımlı bataryanın şarjlılık durumu [kWh].

ikili değişken. $z$ periyodunda komşu alan ağı trafodan güç çekiyorsa 1; aksi halde 0 .

ikili değişken. $z$ periyodunda paylaşımlı batarya şarj oluyorsa 1; aksi halde 0 .

ikili değişken. $z$ periyodunda $e$ evi OBN'den güç çekiyorsa 1 ; aksi halde 0 .

ikili değişken. Sistem operatörü tarafından tanımlanan kredi limitine ulaştıktan sonra $z$ periyodunda $e$ evi OBN'ye enerjiyi geri veriyorsa 1 ; aksi halde 0 .

katsayılar matrisi.

çıkış vektörü.

\section{Giriş}

Elektrik güç sistemleri içerisindeki yenilenebilir enerji kaynaklarının kapasitelerinin hızlı bir şekilde artması sonucunda sistemlerde enerji arzı ve talebi dengesinin sağlanmasında sorunlar ortaya çıkmaya başlamıştır. Özellikle sabit olması gereken gerilim ve frekans değerlerinde önemli dalgalanmalara sebep olan bu sorunların çözümü için gerçek uygulamalarda ve literatürde en çok benimsenen yaklaşımlar talep cevabı uygulamaları [1,2], elektrik enerjisi depolama sistemlerinin kullanımı [3,4] ve tahmin yöntemlerinin mevcut sistemlere entegre edilmesidir [5,6].

Belirtilen çözüm yöntemleri içerisinde talep cevabı uygulamaları, özellikle yüksek güç tüketimi değerlerine sahip olan endüstriyel ve ticari yükler ile birlikte kullanıldıklarında şebekelerdeki enerji talebinin kontrol edilmesinde oldukça etkili olmaktadırlar. Son yıllarda ise şebekelerdeki toplam tüketim değerleri içerisinde evlere ait olan payın önemli oranda artması ile birlikte, belli bir sayıdaki evin de enerji arz talebi dengesinin sürdürülebilmesinde oldukça etkili olabileceği görülmüştür [7-9]. Bu nedenle, enerji dağıtım sistemlerindeki yük taleplerini en düşük maliyetlerle ve en az güç kaybı ile karşılayabilmek amacıyla literatürdeki çok sayıda çalışmada evsel ölçekteki talep cevabı uygulamalarına dayanan yöntemler geliştirilmiştir. Muratori ve Rizzoni [10] evsel kontrol edilebilir elektrikli eşyaların kullanımında en uygun planlamayı yaparak şebekeye destek sağlayabilecek bir enerji yönetimi yaklaşımı önermişlerdir. Klimaları ve ötelenebilir (shiftable) yükleri kontrol ederek şebekelerdeki enerji iletimi tıkanıklığı (congestion) sorununa bir çözüm bulabilmek ve tüketici maliyetleri açısından bir tasarruf sağlamak amacıyla Siano ve Sarno [7], yük talebindeki, hava koşullarındaki ve kullanıcı tercihlerindeki belirsizlikleri modellemeye çalışmışlardır. Tüketicilerin maliyetlerini azaltmak ve aynı zamanda şebekedeki pik yük talebini farklı zamanlara yayabilmek amacıyla evsel yükleri sınıflandıran ve bu sınıflara göre bir yük planlaması gerçekleştiren bir yöntem ise [11]'de önerilmiştir. Bazı çalışmalarda ise şebekelere sağlanabilecek faydalardan daha çok tüketicilerin elde edebileceği faydalara odaklanılmıştır. Hu vd. [12] tüketicilerin evsel talep cevabı programlarına katılımını artırabilmek amacıyla bir konfor göstergesi tanımlamışlardır ve tüketicilerin katılım oranlarına göre belirlenen bir ödül sistemi geliştirmişlerdir. Tüketicilerin enerji kullanım maliyetlerini azaltabilmek amacıyla benzeri bir teşvik mekanizması [2]'de önerilmiştir. Farklı evsel cihazların talep cevabı programları içerisinde kullanılmaya uygunlukları ve kullanılmaları durumunda sağlayabilecekleri ekonomik faydalar ise [13]'te ayrıntılı bir şekilde değerlendirilmiştir. Evsel talep cevabı programlarının tüketicilere ve dağıtım sistemi işletmecilerine sağladıkları faydaları inceleyen çok sayıda çalışma ve bu çalışmalara ait özet bilgiler [14] ve [15]'te bulunabilir.

Literatürdeki çeşitli çalışmalarda ise talep cevabı yöntemlerinin etkinliğini artırabilmek amacıyla evlerin üreten tüketiciler (prosumers) olmaları durumu göz önüne alınmıştır. Lu vd. [16] fotovoltaik (PV) panellere sahip belirli bir sayıda evin tüketim değerlerini, üretim değerlerine göre ayarlayabilmek ve bu sayede bir enerji depolama sistemine olabilecek ihtiyacı ortadan kaldırabilmek amacıyla talep cevabı tabanlı bir enerji yönetimi algoritması önermişlerdir. Aynı amaçla Venizelou vd. [17] çok sayıda ev için yeni bir kullanım zamanlı (time-of-use - ToU) tarife geliştirmişlerdir. Bir depolama sistemine sahip olmayan oldukça fazla sayıda üreten tüketicinin talep cevabı programlarına katılmasıyla elde edebileceği karı artırabilmek amacıyla bir model öngörülü kontrol yöntemi ise [18]'de sunulmuştur.

Evsel yüklerle birlikte elektrik enerjisi depolama sistemlerinin kullanımı, bazı kısa süreli üretim - tüketim dengesizlikleri durumunda şebekeye enerji verilerek veya şebekeden enerji alınarak yaşanabilecek sorunların önüne geçmeyi kolaylaştırmaktadır. Belirtilen enerji depolama sistemlerinin bir diğer faydası ise bu sistemlerin, değişken bir üretime sahip olan yenilenebilir enerji kaynaklarının üretimini, üretim miktarının tüketimden fazla olduğu zamanlarda fazla enerjiyi depolayarak, tüketimin fazla olduğu zamanlarda ise depolanan enerjiyi kullanarak daha dengeli ve belli bir ölçüde kontrol edilebilir hale getirmesidir [19,20]. Bu nedenle evsel uygulamalarda yenilenebilir enerji kaynakları genellikle depolama sistemleri ile birlikte kullanılmaktadırlar. Son yıllarda yapılan çalışmalarda, evsel yükler için depolama sistemlerinin kullanılması durumunda evlere ait olan yenilenebilir enerji kaynaklarından daha etkin bir şekilde faydalanılabileceği ve talep cevabı uygulamalarında elde edilebilecek faydaların artırılabileceği açıkça ortaya konmuştur. Nan vd. [21] her bir evin bir PV ünitesine ve bataryaya sahip olduğu varsayılan bir bölgede tüketici maliyetlerini ve şebekedeki pik yük talebini azaltmak amacıyla evsel yüklerin kullanımı için bir planlama stratejisi önermişlerdir. Evlerdeki PV 
ünitelerden en ekonomik olarak faydalanılabilmesi amacıyla evsel yüklerin kontrol edilmesine dayanan bir yaklaşım, farklı PV ünitesi ve batarya kapasiteleri için [11]'de incelenmiştir. Sivaneasan vd. [22] PV panellerinin güç üretimindeki süreksizliği azaltabilmek amacıyla binalardaki klima yüklerini ve bataryaları kullanan bir enerji yönetimi yaklaşımı sunmuşlardır. Evlere ait PV panellerin üretimleri ile evlerdeki güç tüketimlerini adapte edebilmek amacıyla talep cevabı uygulamalarının ve bir enerji depolama sisteminin kullanımına dayanan bir yöntem [23]'te verilmiştir. Talep cevabı programlarının, PV ünitelerinin ve depolama sistemlerinin birlikte kullanımı ile ilgili daha geniş çaplı bilgiye ve daha fazla sayıda çalışmaya [24]’te ulaşılabilir.

Evlerdeki mevcut alanların bataryaların konumlandırılması açısından yetersiz olması, bataryaların gürültü ve 1sı problemlerine sahip olması ve bireysel batarya kullanımında ilk yatırım, bakım ve değişim maliyetlerinin yüksek olması nedeniyle son yıllarda literatürdeki çalışmalarda evsel yenilenebilir enerji kaynakları ile birlikte bir batarya kullanmak yerine çok sayıda ev için tek bir yüksek güçlü batarya kullanılmak fikri ortaya atılmıştır. Özellikle maliyet açısından son kullanıcılara sağladıkları faydalara ek olarak, bahsedilen paylaşımlı bataryaların bir diğer önemli özelliği ise sahip oldukları yüksek enerji kapasitesi sayesinde gerektiğinde şebekedeki pik yük talebini azaltmak için kullanılabilmeleridir. Bu amaçla, PV ünitelere sahip olan evsel kullanıcıların bulunduğu bir bölgede paylaşımlı bataryaların optimum konumlandırılması, boyutlandırılması ve işletimi [25]'te incelenmiştir. Wang vd. [26] PV ünitelerinin üretim değerlerinin şebeke içerisindeki payını artırmak amacıyla evsel talep cevabı uygulamalarından ve paylaşımlı bataryalardan faydalanmışlardır. Aynı sistem yapısı için enerji maliyeti ve tüketici memnuniyeti arasındaki ilişki [27]'de araştırılmıştır. Ayrıca, paylaşımlı bataryaların talep cevabı programları ile birlikte kullanılması durumunda sistem işletmecilerinin ve tüketicilerin en yüksek oranda kar etmesini sağlamak amacıyla [8,9]'da teşvik tabanlı bir yöntem önerilmiştir.

Bahsedilen gerilim ve frekans ile ilgili problemlerin çözümü için yaygın olarak kullanılan üçüncü yöntem ise yenilenebilir enerji kaynaklarından elde edilebilecek olan enerjinin ve tüketicilere ait beklenen yük taleplerinin belirli bir süre için tahmin edilmeye çalışılmasıdır [28-30]. Yüksek güçlü yenilenebilir enerji santralleri ve belirli bir alandaki çok sayıda tüketiciye ait toplam güç için bahsedilen tahmin yöntemleri uzun yıllardır etkin bir şekilde kullanılmaktadır. Özellikle son yıllarda bilgi ve haberleşme teknolojilerindeki gelişmeler ile birlikte evsel kaynaklardan ve tüketicilerden farklı zaman ölçeklerinde ve uzun süreli olarak veri toplamanın mümkün hale gelmesiyle birlikte evsel ölçekte üretim ve tüketim değerlerinin tahmini için de yöntemler geliştirilmeye ve kullanılmaya başlamıştır [6,31].

Bu çalışmada, dağıtım şebekelerindeki üretim ve tüketim değerleri arasındaki dengesizliklerini azaltabilmek amacıyla yukarıda bahsedilen üç farklı yöntemden de faydalanabilecek bir yaklaşım önerilmektedir. Bu amaçla, öncelikle aynı bölge içerisinde yer alan ve aynı trafodan beslenen belirli bir sayıdaki ev göz önüne alınmıştır. Evlerin tamamı dağıtım sistemi işletmecisi ile yaptıkları anlaşmalar gereği günün belirli saatlerinde bir talep cevabı etkinliğine katılmaktadırlar. Ayrıca önerilen yöntemin etkinliğini gösterebilmek amacıyla tüm evlerin PV panellere sahip olduğu ve çift yönlü elektrik sayaçları sayesinde dağıtım şebekesi ile enerji alışverişi yapabildikleri varsayılmıştır. Evlerin üretim fazlası enerjilerini depolamak için daha önceden belirtilen avantajları nedeniyle bir paylaşımlı batarya ünitesinin sistem içerisinde mevcut olduğu ve her birin evin sisteme (diğer evlere veya paylaşımlı bataryaya) sağladığı enerji karşılığında, sonradan kullanabileceği bir enerji kredisi kazandığı düşünülmüştür. Son olarak, önerilen enerji yönetimi yaklaşımı, kullanıcılar açısından enerji tüketimi maliyetlerini azaltmak ve sistem işletmecisi açısından pik yük talebi periyotlarında şebekeye aktif güç sağlayarak destek olmak amacıyla her bir son kullanıcı için PV üretimi ve güç tüketimi tahminlerini karar verme aşamalarında dikkate almaktadır.

Literatürde paylaşımlı depolama sistemlerinin işletiminde yenilenebilir enerji ve yük talebi tahminlerini birlikte kullanmayı öneren çok az sayıda çalışma bulunmaktadır. Huang ve Sun [32], PV paneller, bataryalar ve farklı ticari tüketiciler içeren bir sistemin işletimde yük tahminlerine ait belirsizlikleri dikkate almışlardır. Ancak önerilen çalışmada, bir talep cevabı yöntemi kullanılmamıştır ve istatistiksel dağılımlara dayanan tahmin yöntemi ile bu tahminlerin nasıl elde edildiğine ait bilgilere yer verilmemiştir. Üreticilere ve tüketicilere ekonomik faydalar sağlamak amacıyla paylaşımlı depolama sistemi ve son kullanıcılardan oluşan bir sistemdeki enerji ticareti [33]'te incelenmiştir. Çalışmada enerji üretimi ve tüketimi tahminleri göz önüne alınmıştır, ancak bir tahmin yönteminden elde edilmeyen ve doğru oldukları kabul edilen bu değerlerin kullanılması ile varsayımlara bağlı sonuçlar elde edilmiştir. Belirtilen varsayımların incelendiği bir başka çalışmada [34], yük talebi tahminlerinin tamamen doğru olduğu ve hatalar içerdiği iki durumun karşılaştırılması sonucunda, tahmin değerlerinde mevcut olan hataların, paylaşımlı bataryaların sağlayabileceği faydalar üzerinde önemli bir etkisi olduğu gösterilmiştir. Bahsedilen çalışmada, bu yayında önerilen yaklaşımdan farklı olarak bir talep cevabı uygulaması ve evlerin dağıtık enerji üretimi sistemlerine sahip olmaları durumları göz önüne alınmamıştır.

Önerilen yöntemin aynı alandaki literatüre katkıları aşağıda maddeler halinde verilmektedir:

- Bu çalışmada literatürde az sayıda yayında incelenen paylaşımlı elektrik enerjisi depolama sistemlerinin son kullanıcılara ve dağıtım sistemi işletmecisine sağladığı faydalar araştırılmıştır.

- Ayrıca dağıtım sistemi işletmecisine şebekedeki enerji yönetiminde daha fazla esneklik sağlamak amacıyla paylaşımlı batarya ile birlikte bir teşvik tabanlı talep cevabı programı dikkate alınmıştır.

- $\quad$ PV ünitelere sahip belli bir sayıda evsel tüketicinin bulunduğu ve gerçek zamanlı enerji fiyat tarifesinin uygulandığı bir bölge için etkinliği test edilen yaklaşım içerisinde son kullanıcılara, elektriğin birim fiyatının yüksek olduğu zamanlarda kullanmak üzere, sisteme verdikleri enerji miktarı kadar enerji kredisi verilerek önerilen yaklaşımdaki karlılığın artırılması hedeflenmiştir.

- Yük talebi ve PV güç üretimine ait gelecekteki değerlerinin mevcut olduğunun varsayıldığı literatürdeki diğer çalışmalardan farklı olarak önerilen yöntemde gerçek uygulamalarda kullanabilmek amacıyla bir günlük tüketim ve üretim değerleri tüm tüketiciler için bir tahmin yöntemi ile elde edilmiştir.

- Belirtilen tahmin değerlerini yüksek bir doğrulukta elde edebilmek için literatürde özellikle son birkaç yılda ön plana çıkan ve bu çalışmadaki duruma benzer şekilde farklı noktalardan farklı zamanlarda alınan verilerin mevcut olması durumunda bu veriler arasında bir ilişki kurmakta oldukça başarılı olduğu gözlemlenen uzamsal-zamansal tahmin yöntemleri kullanılmıştır. 
- Son olarak, paylaşımlı batarya kullanımına dayanan ve evsel yenilenebilir enerji üretimi ile birlikte gerçek zamanlı elektrik tarifesini dikkate alan talep cevabı yaklaşımı için en yüksek faydayı sağlayabilecek başlangıç ve bitiş saatlerinin belirlenmesinde literatürde ilk defa talep ve yenilenebilir enerji üretimi tahminlerinden faydalanılmıştır.

Bu çalışmada göz önüne alınan sisteme ve önerilen yönteme ait ayrıntılı bilgiler Bölüm 3’te verilmektedir. Yöntemin etkinliği ise gerçek verilerin kullanıldığı bir durum üzerinde Bölüm 4'te test edilmiştir. Son olarak, elde edilen en önemli sonuçlar ve önerilen yöntemin geliştirilebilmeye açık yönleri Bölüm 5'te verilmiştir.

\section{3. Önerilen Sistem Yapısı}

$\mathrm{Bu}$ çalışmada önerilen sistemin genel yapısı Şekil 1'de gösterilmektedir. Aynı bölge içerisinde bulunan ve her biri farklı güçlerde PV panellere olan sahip belirli bir sayıda evin ortak bir transformatör üzerinden beslendiği bu sistemde evlere ait üretim ve tüketim değerleri tahminlerine göre kullanılan bir paylaşımlı enerji depolama sistemi bulunmaktadır. Şekil 1'den görülebileceği üzere evler, paylaşımlı depolama ünitesi ve transformatör, ortak bağlantısı noktası (OBN) adı verilen aynı noktaya bağlıdırlar. Sistemde evler ihtiyaç duydukları enerji miktarını öncelikle kendi PV üretimlerinden, bu üretimin yetersiz olması durumunda ise diğer evlerin ihtiyaç fazlası üretiminden, paylaşımlı depolama ünitesinden veya şebekeden karşılamaktadırlar. Benzer şekilde, evler ihtiyaçlarından fazla ürettikleri enerjilerini akıllı sayaçları üzerinden diğer evlere ve şebekeye satabilmekte veya paylaşımlı depolama ünitesinde depolayabilmektedirler. Ayrıca, şebeke ile paylaşımlı depolama ünitesi arasında da iki yönlü bir enerji akışı mümkün olmaktadır. Son olarak, önerilen sistemde paylaşımlı depolama sisteminin etkinliğinin artırılabilmesi amacıyla evlerinin tamamının saatlik elektrik fiyat tarifesine tabi oldukları varsayılmıştır.

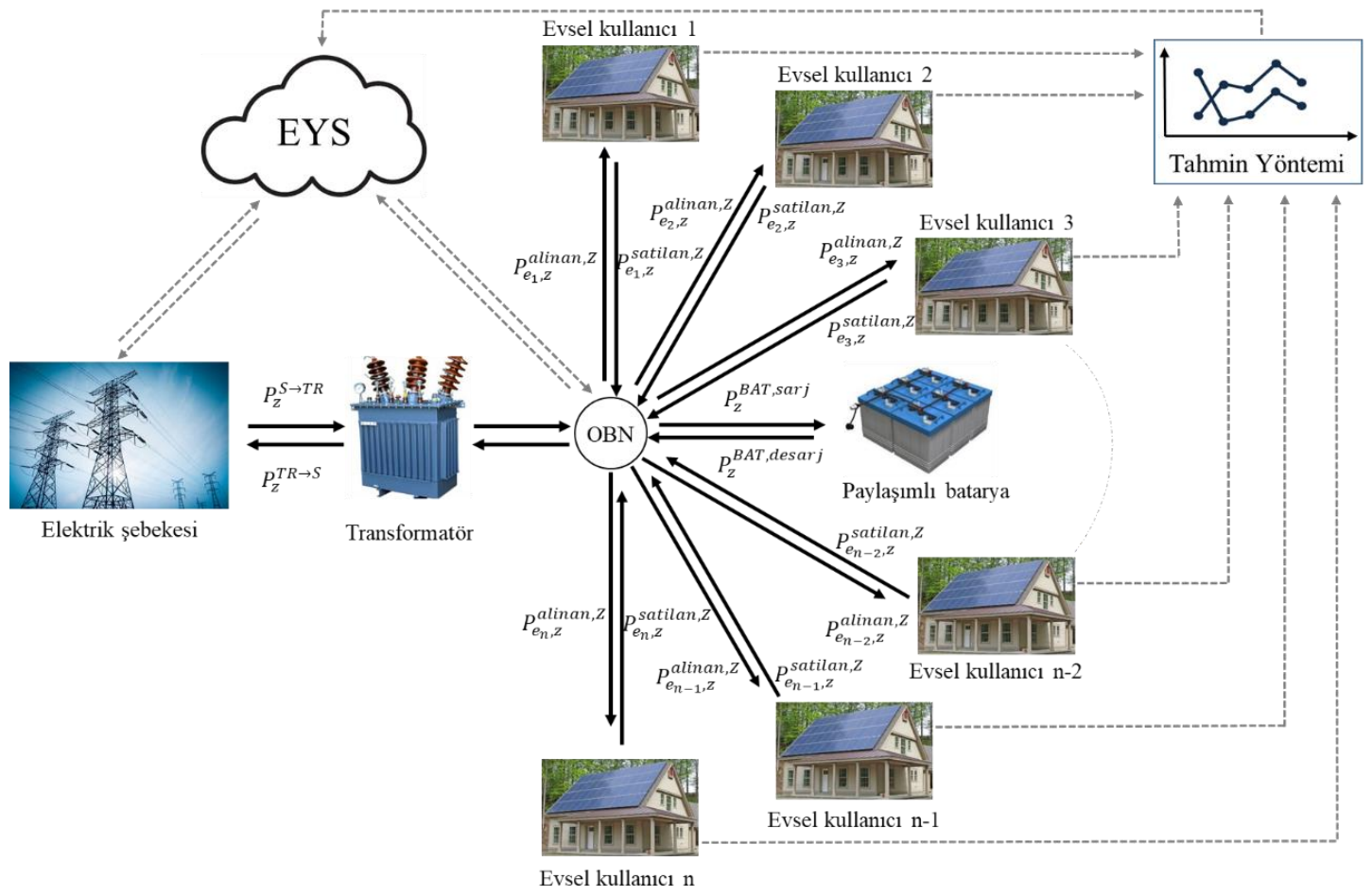

Şekil 1. Evsel kullanıcılardan ve bir paylaşımlı depolama ünitesinden oluşan sistem yapısı.

Bahsedilen sistem yapısından en etkin şekilde faydalanabilmek amacıyla sisteme ait bileşenler ve önerilen enerji yönetimi yaklaşımı bir optimizasyon problemi olarak tanımlanmıştır. Önerilen probleme ait amaç fonksiyonu ve kısıtlar eşitlikler (1)-(30) ile verilmektedir [9].

Minimize et

$$
\text { TTEM }=\sum_{e} \sum_{Z}\left(\lambda_{z}^{\text {alinan }} \cdot\left(P_{e, z}^{\text {alinan }, T}-P_{e, z}^{\text {alinan }, B A T}\right) \cdot \Delta Z-\lambda_{z}^{\text {satilan }} \cdot\left(P_{e, z}^{\text {satilan }, T}-P_{e, z}^{\text {satilan }, B A T}\right) \cdot \Delta Z\right), \forall e
$$

Öyle ki,

$$
\begin{aligned}
P_{e, Z}^{\text {alinan }, T} & =P_{e, Z}^{\text {alinan }, Y}+P_{e, Z}^{\text {alinan }, S}+P_{e, Z}^{\text {alinan }, B A T}, \forall e, Z \\
P_{e, Z}^{\text {satilan }, T}= & P_{e, Z}^{\text {satilan }, Y}+P_{e, Z}^{\text {satilan }, S}+P_{e, Z}^{\text {satilan }, B A T}, \forall e, Z \\
& \sum_{e} P_{e, Z}^{\text {alinan }, Y}=\sum_{e} P_{e, Z}^{\text {satilan }, Y}, \forall Z
\end{aligned}
$$


Avrupa Bilim ve Teknoloji Dergisi

$$
\begin{aligned}
& \sum_{e} P_{e, z}^{\text {alinan }, S}=P_{z}^{T R \rightarrow K}, \forall z \\
& \sum_{e} P_{e, Z}^{\text {satilan }, S}=P_{z}^{K \rightarrow T R}, \forall z \\
& P_{Z}^{S \rightarrow T R}=P_{Z}^{T R \rightarrow K}+P_{Z}^{T R \rightarrow B A T}, \forall Z \\
& P_{Z}^{T R \rightarrow S}=P_{Z}^{K \rightarrow T R}+P_{Z}^{B A T \rightarrow T R}, \forall Z \\
& P_{z}^{S \rightarrow T R} \leq S \cdot u_{z}^{1}, \forall z \\
& P_{Z}^{T R \rightarrow S} \leq S \cdot\left(1-u_{z}^{1}\right), \forall Z \\
& 0 \leq P_{z}^{B A T, s a r j} \leq L^{B A T, s a r j} \cdot u_{z}^{2}, \forall Z \\
& 0 \leq P_{z}^{B A T, \text { desarj }} \leq L^{B A T, \text { desarj }} \cdot\left(1-u_{z}^{2}\right), \forall z \\
& S O E_{Z}^{B A T}=S O E_{Z-1}^{B A T}+S V^{B A T} \cdot P_{z}^{B A T, \text { sarj }} \cdot \Delta Z-\frac{P_{z}^{B A T, \text { desarj }}}{D V^{B A T}} \cdot \Delta Z, \text { if } z>1 \\
& S O E^{B A T, \min } \leq S O E_{z}^{B A T} \leq S O E^{B A T, m a k s}, \forall z \\
& S O E_{z}^{B A T}=S O E^{B A T, i l k}, \forall e, \text { ĕger } z=1 \\
& P_{Z}^{B A T, s a r j}=P_{Z}^{K \rightarrow B A T}+P_{Z}^{T R \rightarrow B A T}, \forall Z \\
& P_{z}^{B A T, \text { desarj }}=P_{Z}^{B A T \rightarrow K}+P_{Z}^{B A T \rightarrow T R}, \forall Z \\
& P_{Z}^{B A T \rightarrow K}=\sum_{e} P_{e, z}^{\text {alinan }, B A T}, \forall Z \\
& P_{z}^{K \rightarrow B A T}=\sum_{e} P_{e, z}^{\text {satilan } B A T}, \forall z \\
& P_{e, z}^{\text {alinan }, T}+P_{e, z}^{P V, \text { kullanilan }}=Y_{e, z}, \forall e, z \\
& P_{e, Z}^{\text {alinan }, T} \leq S \cdot u_{e, Z}^{3}, \forall e, Z \\
& P_{e, Z}^{\text {satilan }, T} \leq S \cdot\left(1-u_{e, z}^{3}\right), \forall e, z \\
& P_{e, Z}^{P V, \text { kullanilan }}+P_{e, z}^{\text {satilan }, T}=P_{e, z}^{P V, \text { uretim }}, \forall e, z \\
& E_{e, Z}^{k r e d i}=E_{e, Z-1}^{k r e d i}+P_{e, z}^{\text {satilan }, B A T} \cdot \Delta Z-P_{e, z}^{\text {alinan }, B A T} \cdot \Delta Z, \forall E, \text { ĕg } e r z>1 \\
& E_{e, z}^{k r e d i}=E_{e}^{k r e d i, i l k}, \forall e, \text { ĕger } z=1 \\
& P_{e, z}^{\text {satilan }, B A T}=0, \forall e, z \in\left[Z^{\text {DR_baslangic }}, Z^{D R_{-} \text {bitis }}\right] \\
& P_{e, z}^{\text {alinan }, B A T}=0, \forall e, z \notin\left[Z^{D R_{-} \text {baslangic }}, Z^{D R_{-} \text {bitis }}\right] \\
& E_{e}^{k r e d i}=\frac{S O E^{B A T, m a k s}-S O E^{B A T, i n i}}{E}, \forall e \\
& E_{e, z}^{k r e d i} \leq E_{e}^{k r e d i}, \forall e, z \\
& S O E_{z}^{B A T} \geq \sum_{e} E_{e}^{\text {kredi }}+S O E^{B A T, \min }, \text { ĕger } z=Z^{D R_{-} \text {baslangic }}
\end{aligned}
$$


Tanımlanan optimizasyon probleminin amaç fonksiyonu eşitlik (1)'de gösterildiği gibi tüketicilerin toplam enerji maliyetlerini (TTEM) en aza indirmek olarak belirlenmiştir. Her bir eve ( $e$ ) ait belirli bir zamanda $(z)$ satın alınan güç miktarı eşitlik (2)'de gösterildiği gibi, diğer evlerin PV üretimden gelen güç $\left(P_{e, z}^{\text {alinan,Y }}\right)$, şebekeden gelen güç $\left(P_{e, z}^{\text {alinan }, S}\right)$ ve paylaşımlı bataryadan gelen güç $\left(P_{e, z}^{\text {alinan,BAT }}\right)$ olmak üzere üç bileşene ayrılmıştır. Her bir evin belirli bir anda sattığı güç miktarı da benzer şekilde, diğer evlere verilen güç $\left(P_{e, z}^{\text {satilan,Y }}\right)$, şebekeye verilen güç $\left(P_{e, z}^{\text {satilan,G }}\right)$ ve paylaşımlı bataryaya verilen güç $\left(P_{e, z}^{\text {satilan,BAT }}\right)$ olmak üzere üç bileşenden oluşmaktadır.

Eşitlik (4) PV paneller tarafindan üretilen gücün her bir $z$ zamanında evler tarafından kullanılan PV gücüne eşit olması gerektiğini göstermektedir. Şebekeden evlere gelen güç (5) ile ifade edilirken evler tarafından şebekeye aktarılan güç ise (6) ile tanımlanmaktadır. Kısıt (7) şebekeden gelen gücün, evlere ve paylaşımlı depolama sistemine gelen toplam güce eşit olduğunu; kısıt (8) ise şebekeye giden gücün evlerden ve depolama ünitesinden giden toplam güce eşit olduğunu göstermektedir. Eşitlikler (9) ve (10) ise aynı anda hem evlerden şebekeye hem de şebekeden evlere enerji akışının önüne geçmek için kullanılmaktadır.

Paylaşımlı depolama sistemine ait eşitlikler ise (11)-(19) arasında tanımlanmıştır. Sisteme ait şarj ve deşarj güçleri (11) ve (12) ile sınırlandırılırken bu eşitliklerde ikili değişken $\left(u_{t}^{2}\right)$ ile şarj ve deşarjın aynı anda gerçekleşmesinin önüne geçilmektedir. Depolama ünitesinin zamanla değişen enerji durumu (state-of-energy - SOE) (13) ile verilmektedir ve bataryanın derin deşarjı ve aşırı şarjı (14) ile önlenmektedir. Eşitlik (15) bataryanın ilk durumdaki şarjını ifade etmektedir. Eşitlikler (16) ve (17) sırasıyla bataryanın evlerden gelen ve şebekeden gelen güç ile şarj olabileceğini ve deşarj durumunda ise gücün evlere ve şebekeye aktarılacağını göstermektedir. Son olarak, (18) ve (19) şebekeye giden ve şebekeden gelen bataryaya ait güç miktarlarını ifade etmektedir.

Evlere ait güç değişimleri (20)-(23) ile verilmektedir. Kısıt (20) her bir ev için güç dengesini, (21) ve (22) ise evler ve şebeke arasındaki her bir anda sadece tek bir yönde olabilecek güç değişimlerini göstermektedir. Eşitlik (23) evlerin, kendilerine ait PV üniteler ile ürettikleri güçleri kullandıklarını, ihtiyaç fazlası gücü ise sattıklarını ifade etmektedir.

Evlere ait toplam enerji maliyetini en aza indirmek ve şebekelerde pik yük talebini azaltmak amaciyla önerilen enerji yönetimi yaklaşımına ait eşitlikler ise (24)-(30) ile tanımlanmaktadır. Kısıt (24) her bir evin paylaşımlı depolama ünitesine sağladığı enerji kadar enerji kredisi kazandığını ve bu üniteden aldığı enerji miktarı oranında da kazandığı kredileri harcadığını göstermektedir. Her bir evin ilk anda sahip olduğu enerji kredisi (25) ile verilmektedir. Eşitlikler (26) ve (27) paylaşımlı depolama sisteminden en yüksek oranda fayda sağlayabilmek amacıyla depolama sisteminin bir talep cevabı uygulaması dışında kalan zamanlarda yalnızca şarj edildiğini, uygulama zamanı içerisinde ise yalnızca deşarj edildiğini göstermektedir. Önerilen amaç fonksiyonu dikkate alındığında bataryanın çoğunlukla enerjinin birim fiyatının en az olduğu zamanlarda şarj olacağı ve enerji fiyatının en yüksek olduğu zamanlarda ise deşarj olacağ1 öngörülebilir. Eşitlikler (28) ve (29) ise her bir eve ait önceden belirlenmiş eşit miktarda bir enerji kredisi olduğunu ve kazanılabilecek kredilerin her bir zaman diliminde bu değer ile sınırlandırıldığını ifade etmektedir. Son olarak kısıt (30), talep cevabı uygulaması esnasında tüm evlere kazandıkları enerji kredisi kadar enerji sağlayabilmek amacıyla uygulamanın ilk anında paylaşımlı depolama sisteminde olması gereken en az güç miktarını vermektedir.

Önerilen yaklaşımda her bir evin kendisi için ayrılan kredi miktarına ulaşması durumunda ihtiyaç fazlası enerjisini şebekeye satabileceği varsayılmıştır. Benzer şekilde evler, kredilerinin tamamını kullandıktan sonra şebekedeki mevcut fiyattan enerji alımına devam edeceklerdir. Farklı fiyatlardaki enerji alışverişlerinin tüketicilerin enerji maliyetini en aza indireceği ve ayrıca enerjinin pahalı olduğu pik yük talebi zamanlarında evler genellikle kredilerini kullanacağı için pik yük talebini azaltacağı öngörülmektedir.

Dağıtım şebekelerinde enerji arzı ve talebi arasındaki dengenin sürekli olarak korunması amacıyla yenilenebilir enerji kaynaklarının kullanımına dayanan talep cevabı yöntemlerini ve paylaşımlı depolama ünitelerini aynı sistem içerisinde dikkate alan çalışmalarda kayda değer sonuçlar elde edilirken, bu çalışmaların tamamında evlere ait üretim ve tüketim değerlerinin önceden mevcut olması gibi önemli bir varsayım yapılmıştır. Bu varsayıma göre genellikle bir sonraki güne ait üretim ve tüketim verilerinin önerilen yöntemlere giriş olarak uygulanması ile aynı gün için bir optimum enerji yönetimi planlaması yapılmaktadır. Ancak gerçek uygulamalarda böyle bir veri mevcut olmayacağı için istenen değerlerin elde edilebilmesi amacıyla genellikle izlenen iki yaklaşım bulunmaktadır. İlk yaklaşım, literatürdeki farklı alanlarda da kullanılan, mevcut verinin günlere ve haftalara göre sınıflandırılması ve istenen gün için üretim ve tüketim değerlerinin, benzeri şartları sağlayan bir başka gün ile aynı olacağının varsayılmasıdır. Başka bir ifadeyle, bu yaklaşımda, enerji planlaması yapılması istenen güne ait üretim ve tüketim değerlerinin bir önceki gün ile veya bir önceki haftadaki aynı gün ile tamamen aynı olacağı kabul edilmektedir. Bazı çalışmalarda ise belirli bir güne ait verilerin elde edilmesinde benzer özellikleri taşıyan ve ölçü̈mleri mevcut olan günlerin tamamı farklı ağılıklandırma katsayıları ile birlikte kullanılmaktadır. Bahsedilen yaklaşım tamamen varsayımlara dayandığı için genellikle gerçek değerlerden oldukça uzak değerler sağlamaktadır. Bu nedenle belirtilen yaklaşımın kullanıldığı yayınlarda, çalışmaların temel amacının enerji yönetimi olduğu ve sınıflandırma sonucu elde edilen verilerin doğrulanması gibi bir konunun çalışmanın kapsamı dışında kaldığı belirtilmektedir. İkinci yaklaşımda ise literatürdeki yöntemlerden faydalanılarak belirli süreler için evlere ait enerji üretimi ve tüketimi tahminleri yapılmakta ve enerji planlamasında bu değerler göz önüne alınmaktadır. Bu sayede özellikle gerçek uygulamalarda etkin bir şekilde kullanılabilecek daha yüksek doğruluğa sahip üretim ve tüketim değerleri elde edilebilmektedir. Bahsedilen nedenlerden dolayı, önerilen çalı̧̧mada, evsel talep cevabı ile birlikte paylaşımlı depolama ünitesinin kullanıldığı bir sistemin uygulanabilirliğini ve etkinliğini artırmak amacıyla literatürde ilk defa tahmin yöntemlerinden faydalanılmıştır.

$\mathrm{Bu}$ çalışmada evsel üretim ve tüketim değerleri tahminleri için bir uzam-zamansal tahmin yöntemi kullanılmıştır. Tahmin yöntemleri arasında yüksek doğrulukta tahminler sağlama potansiyeli nedeniyle özellikle son yıllarda ön plana çıkan uzam-zamansal yöntemler, temel olarak farklı noktalardan ve farklı zamanlarda alınan ölçümlerin belirli bir noktadaki kısa süreli tahminler için kullanılması prensibine dayanmakladırlar. Bu yöntemlerde temel amaç, farklı noktalardaki değişkenlere ait ölçüm değerlerinin dikkate alınmasıyla tahmin doğruluğunu artırmaktadır. Bu çalışmada belirli bir sayıda eve ait üretim ve tüketim değerleri mevcut olduğundan uzam-zamansal bir tahmin yönteminin önerilen yönteminin etkinliğini artırmak açısından oldukça uygun olacağ düşünülmüştür. 
Kullanılacak olan yöntem temel olarak bir otoregresif model (autoregressive - AR) tabanlı yöntem olacaktır. AR modeller, bir sistemin çıkış değişkeninin, sisteme ait geçmiş verilerin doğrusal bir kombinasyonu olarak elde edilebileceğini varsayımına dayanırlar. Bu yaklaşımın çok değişkenli sistemlere uygulanmasıyla, çok değişkenli AR modeli (Multivariate Autoregressive - M-AR) eşitlik (31)'deki gibi elde edilebilir:

$$
\begin{gathered}
\boldsymbol{y}(z)=X_{1} \boldsymbol{y}(z-1)+\cdots+X_{n} \boldsymbol{y}(z-n)+e(z) \\
=\sum_{j=1}^{n} X_{j} \boldsymbol{y}(z-j)+e(z)
\end{gathered}
$$

Burada $\boldsymbol{y}(z) \in \mathbb{R}^{P}$ t zamanında $P$ boyutlu bir çıkışı, $X_{j} \in \mathbb{R}^{P x P}$ j'ninci zaman gecikmesi ile ilgili katsayısı matrisini, $n$ model derecesini ve $e(z)$ Gauss gürültüsünü temsil etmektedir. Daha genel bir ifadeyle, $E$ hanede $(e=1,2, \ldots E)$ ölçülen yük verisi için, $y_{z}^{e} z$ örnek zamanında $(z=1,2, \ldots M+n) e$ 'ninci hanede ölçülen yük verisi ve $y^{e^{*}}$ hedef değişken olarak tanımlanabilir. Eşitlik (31)'de verilen M-AR modeli $N:=n P$ ve $P:=E x R$ olmak üzere (32)'de verilen formata dönüştürülebilir.

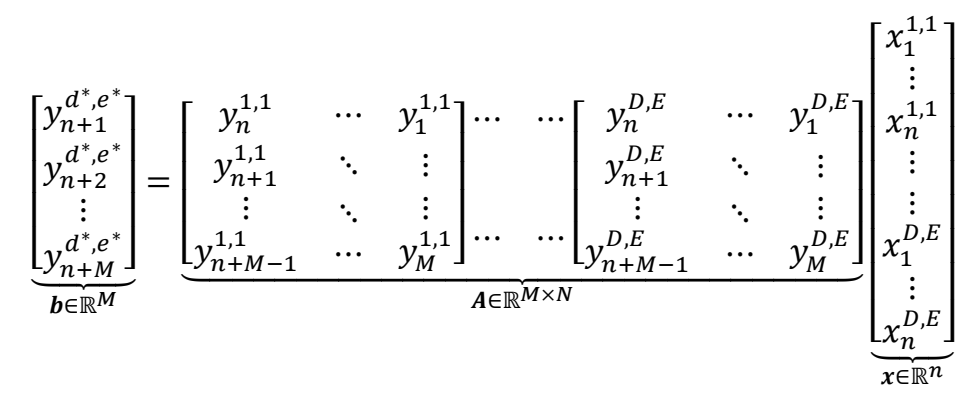

Modele ait eğitim aşamasındaki temel amaç, bir $\boldsymbol{x}$ katsayısı vektörünü belirleyerek $\boldsymbol{b} \in \mathbb{R}^{M}$ ve $A \in \mathbb{R}^{M x N}$ gözlemlerini en iyi şekilde açıklamaya çalışmaktır. Eşitlik (32)'den görülebileceği üzere $\boldsymbol{x}$ vektöründe her bir değişkene ait katsayı bir blok vektörde yer almaktadır. Tüm $n$ derece değerlerinin eşit olduğunun, başka bir ifadeyle, tüm evlerden alınan değişkenlerin tahmin edilmeye çalışılan değişken üzerinde aynı etkiye sahip olduğunun varsayıldığı eşitlik (32)'nin M-AR modelinin farklı $n$ derecelerine sahip değişkenler için düzenlenmiş hali [31]'de ayrıntılı bir şekilde verilmektedir. Önerilen tahmin yaklaşımında her bir tahmin ufku sonunda ölçülmüş̧ olan verilerin modele ait giriş veri setine eklenmesi nedeniyle bir sonraki tahmin ufku için yeni bir $\boldsymbol{x}$ vektörü elde edilmektedir. Son olarak, bahsedilen modellerde $\boldsymbol{x}$ vektör katsayılarının elde edilebilmesi amacıyla bu çalışmada seyrek (sparse) $\boldsymbol{x}$ vektörleri yaklaşımı uygulanmıştır. Bu yaklaşıma ait ayrıntılı açıklamalar ve yaklaşımın tahmin doğruluğu üzerindeki olumlu etkileri [35]’te verilmektedir.

\section{Benzetim Çalışmaları ve Sonuçlar}

Önerilen enerji yönetimi yaklaşımının etkinliğini değerlendirebilmek amacıyla bu çalışmada Austin (ABD) şehrinde ölçülmüşs olan gerçek yük talebi ve PV güç üretimi verilerinden faydalanılmışırı [36]. Çalışmada bu verilerin kullanılmasının sebebi; belirtilen bölgede çok sayıda evde akıllı sayaçlar bulunması nedeniyle kısa süreli zaman ölçeklerinde (beş dakika) tüketim değerlerinin mevcut olması, evlerin önemli bir kısmının PV panellere sahip olması, bu panellerin üretim değerlerinin tüketim değerleri ile aynı zamanlarda kaydedilmiş olması ve son olarak bölgedeki üretim ve tüketim değerlerinin oldukça değişken olmasıdır. Benzetim çalışmaları için evlerde bulunan PV panellere ait üretimin eksiksiz olarak kaydedildiği günler içerisinde güneş ışınımı değerlerinin yüksek olduğu ve bu değerlerin anlık olarak önemli oranlarda değişkenlikler gösterdiği bir gün seçilmiştir. Sonrasında ise istenen özelliklerde verilere sahip çok sayıda ev arasından 20 ev rastgele bir şekilde seçilmiştir. Ev sayısının 20 ile sınırlandırılmasının sebebi, bu evler için kullanılacak olan paylaşımlı depolama sisteminin boyutlarının ve maliyetinin ev sayısının daha fazla artması durumunda teknik ve ekonomik olarak uygun olmaktan çıkmasıdır.

Seçilen evlere ait belirli bir gün boyunca beş dakikalık ölçümlerle alınmış olan tüketim değerleri her bir ev için Şekil 2'de verilmektedir. Şekil 2'den görülebileceği üzere evlere ait enerji tüketimi gün içerisinde düşük seviyelerde iken akşam saatlerinde bu değerler genellikle artmaktadır. Evlerdeki PV güç üretimlerine ait beş dakikalık değerler ise Şekil 3'te verilmektedir. Her bir ev için oldukça değişken değerlere sahip olan PV çıkış güçleri incelendiğinde başta bulut hareketleri olmak üzere çeşitli etkenlerin bu güçler üzerindeki olumsuz etkileri açık bir şekilde görülmektedir. Benzetim çalışmaları için oldukça değişken üretim değerlerinin gözlemlendiği bir günün seçilmesinin nedeni, önerilen enerji yönetimi yaklaşımının ve kullanılan tahmin yönteminin etkinliğinin daha olumsuz şartlar altında incelenmesinin amaçlanmasıdır. Daha az değişken karakteristiğe sahip PV üretimlerinin mevcut olması durumunda enerji yönetimi ve tahmini algoritmalarının daha iyi sonuçlar vereceği belirtilebilir. Son olarak, Şekil 2 ve Şekil 3 'te verilen değerler incelendiğinde, şekillerdeki en yüksek değerlerin günün farklı saatlerinde gözlemlendiği, bu nedenle de seçilen bölgenin bir paylaşımlı batarya kullanımının faydalarının araştırılabilmesi için oldukça uygun olduğu ifade edilebilir. Benzetim çalışmalarında kullanılan bir diğer veri ise elektrik şebekesinden alınan bir günlük elektrik birim fiyatı bilgisidir [37]. Şekil 4'te gösterildiği gibi bu çalışmada bir gerçek zamanlı elektrik fiyatı tarifesi dikkate alınarak elektrik birim fiyatındaki saatlik değişikliklerin de paylaşımlı depolama sistemlerinin etkinliği üzerindeki etkileri araştırılmıştır. 


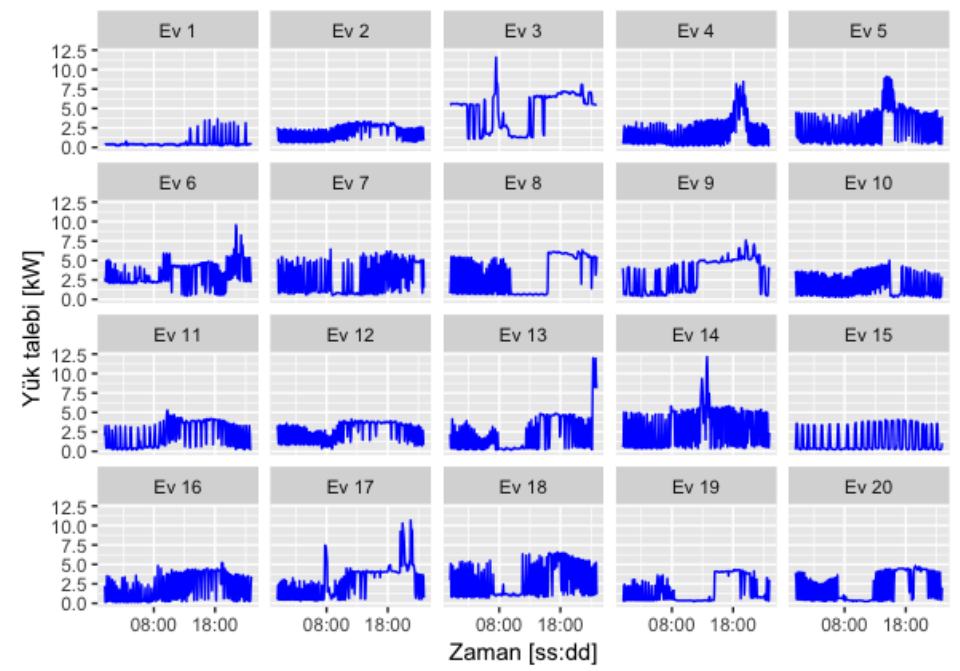

Şekil 2. Seçilen gün için evlere ait beş dakikalık yük talebi değerleri.

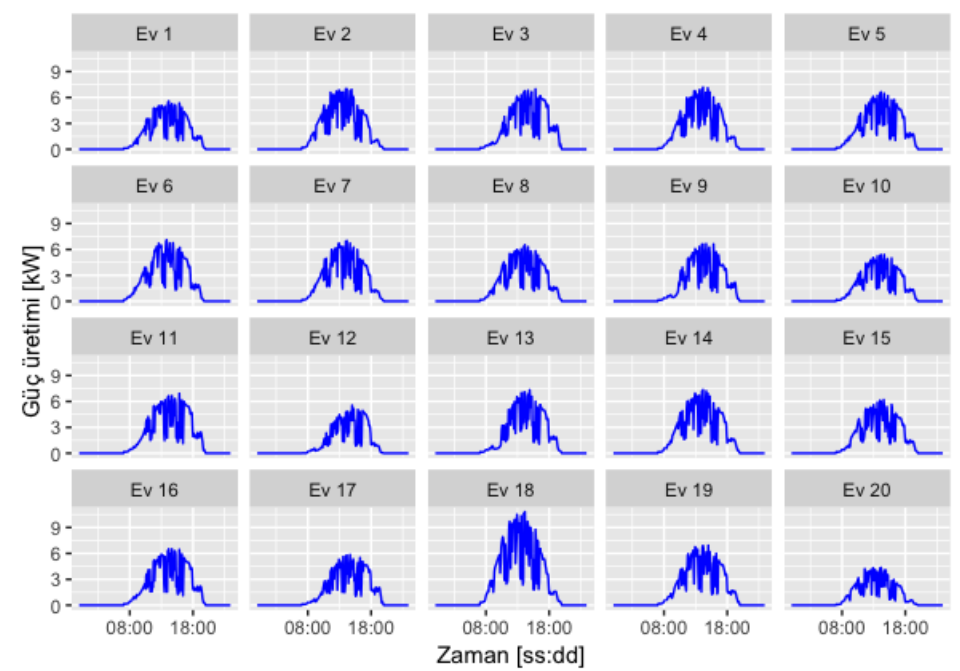

Şekil 3. Seçilen gün için evlere ait beş dakikalık güç üretimi değerleri.

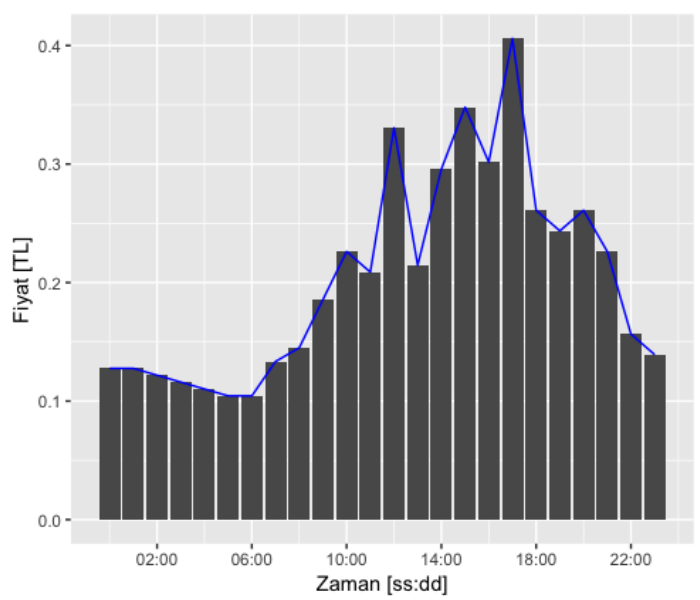

Şekil 4. Seçilen gün için elektrik fiyatının değişimi [37].

Önerilen tahmin tabanlı enerji yönetimi yaklaşımının etkinliğinin değerlendirilebilmesi amacıyla bu çalışmada üç farklı durum göz önüne alınmıştır.

- Durum-1: Paylaşımlı enerji depolama sisteminin mevcut olmadığı durum.

- Durum-2: Paylaşımlı enerji depolama sisteminin mevcut olduğu durum.

- Durum-3: Paylaşımlı enerji depolama sisteminin mevcut olduğu, talep cevabı etkinliği periyodunun yük talebi ve PV çıkış gücü tahminleri göz önüne alınarak belirlendiği durum. 
Benzetim çalışmalarında göz önüne alınan ilk durumda aynı transformatör üzerinden beslenen ve PV panellere sahip olan evlerden oluşan bir dağıtım sistemi göz önüne alınmıştır. Bu sistemin işletiminde her bir evin öncelikle kendi PV ünitesinden elde ettiği enerjiyi kullandı̆̆ı üretim değerlerinin yetersiz olması durumunda ise eksik miktar oranında şebekeden enerji satın aldıkları varsayılmıştır.

İkinci durumda ise ilk durumda göz önüne alınan sisteme, özellikleri Çizelge 1'de verilen bir paylaşımlı enerji depolama ünitesi ilave edilmiştir. Bu sistemin işletimde de öncelikle her bir evin enerji talebini karşılamak amacıyla kendi üretimini kullandığı varsayılmıştır. Enerji üretiminin talepten daha fazla olduğu zamanlarda ihtiyaç fazlası enerji bataryada depolanabilirken; üretiminin talepten düşük olduğu zamanlarda evler, diğer evlere ait PV ünitelerden, paylaşımlı bataryadan ve son olarak dağıtım şebekesinden ihtiyaç duydukları enerjiyi çekmektedirler. Son durumda ise ilk iki durumda önceden belirlenmiş bir parametre olduğu varsayılan talep cevabı başlangıç ve bitiş zamanlarının belirlenmesinde yük talebi ve PV çıkış gücü tahminlerinden faydalanılmıştır.

Çizelge 1. Paylaşımlı Enerji Depolama Ünitesine Ait Parametreler

\begin{tabular}{lcclcc}
\hline Parametre & Ünite & Birim & Parametre & Ünite & Birim \\
\hline$S V^{B A T}$ & 0,95 & - & $S O E^{B A T, i l k}$ & 75 & $\mathrm{kWh}$ \\
$D V^{B A T}$ & 0,95 & - & $S O E^{B A T, m i n}$ & 30 & $\mathrm{kWh}$ \\
$L^{B A T, \text { sarj }}$ & 30 & $\mathrm{~kW}$ & $S O E^{B A T, \text { maks }}$ & 150 & $\mathrm{kWh}$ \\
$L^{\text {BAT,desarj }}$ & 30 & $\mathrm{~kW}$ & & &
\end{tabular}

Üç durumda da yük taleplerinin ve PV çıkış güçlerinin bir uzam-zamansal tahmin yönteminden elde edildiği daha önce belirtilmiştir. Evlere ait bir günlük en ekonomik enerji yönetiminin sağlanabilmesi amacıyla yük talepleri ve PV çıkış güçleri için ilgili günün tamamına ait değerlere ihtiyaç duyulmaktadır. Ancak, mevcut olan beşer dakikalık verilerin kullanılması durumunda bir istatistiksel tahmin yöntemi ile bir günlük tahmin değerlerinin kabul edilebilir bir doğrulukta üretilebilmesi mümkün olmayacăg i için ilgili veriler saatlik ortalama verilere dönüştürülmüştür ve iki değişken için elde edilen bir günlük tahmin değerleri Şekil 5 ve Şekil 6'da gösterildiği gibi elde edilmiştir.

Şekil 5’ten görülebileceği üzere oldukça değişken bir güç tüketimine sahip olan birkaç ev dışındaki tüm evler için gerçeğe yakın tahmin değerleri elde edilmiştir. PV güç üretimleri tahminlerinde ise Şekil 6'dan görülebileceği üzere tahmin doğruluğu daha yukarı seviyededir. Bu tahminlerde gerçeğe daha yakın sonuçlar elde edilebilmesinin iki nedeni bulunmaktadır. İlk neden, 1şınım ve sıcaklık değerlerinin, değişken yük talebi değerlerinin aksine, gün boyunca çoğunlukla belli bir karakteristiğe sahip olmalarıdır. İkinci neden ise, kullanılan tahmin algoritmasının aynı bölgedeki tüm evlere ait güç değerlerini dikkate alması nedeniyle veri setindeki tahmin doğruluğuna olumlu yönde etki edebilecek veri miktarının yüksek olmasıdır.

Elde edilen tahmin değerlerinin doğruluklarını daha iyi anlayabilmek amacıyla literatürde en yaygın olarak kullanılan ortalama mutlak hata (MAE), ortalama küresel hata (RMSE) ve normalleştirilmiş ortalama küresel hata (NRMSE) hata ölçütlerinin minimum, ortalama ve maksimum değerleri her iki değişken için Çizelge 2'de verilmektedir.

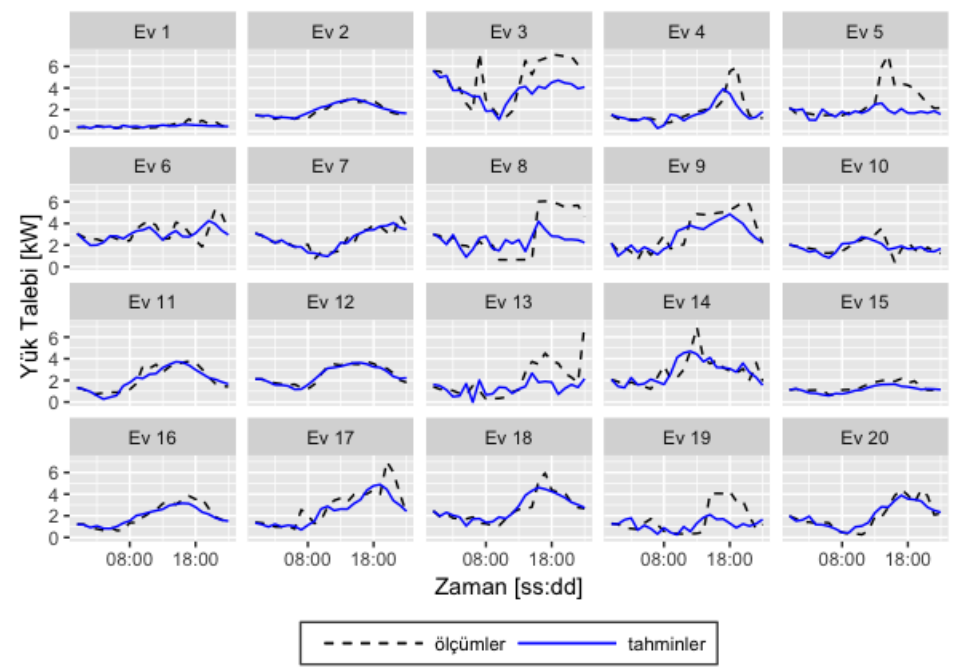

Şekil 5. Seçilen gün için evlere ait saatlik yük talebi tahmini değerleri. 


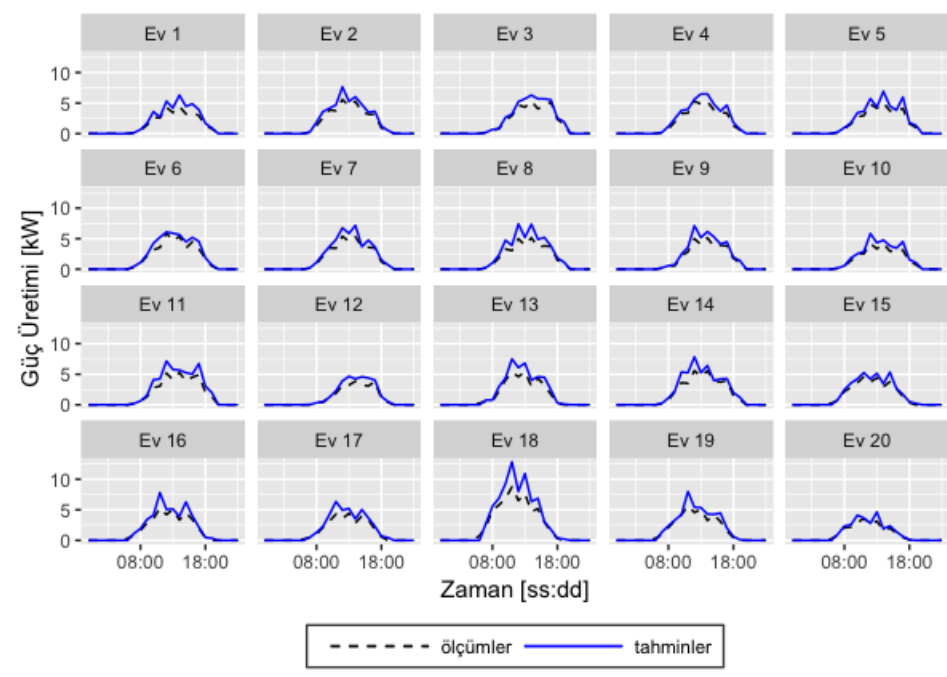

Şekil 6. Seçilen gün için evlere ait saatlik güç üretimi tahmini değerleri.

Çizelge 2. Tahmin Değerlerine Ait Hata Ölçütü Değerleri

\begin{tabular}{l|cccccccccc}
\hline & \multicolumn{3}{|c}{ MAE } & \multicolumn{3}{c}{ RMSE } & \multicolumn{3}{c}{ NRMSE } \\
& \multicolumn{3}{|c}{$[\mathbf{k W}]$} & \multicolumn{3}{c}{$[\boldsymbol{k W}]$} & & \multicolumn{3}{c}{$[\%]$} \\
\hline & Min. & Ort. & Maks. & Min. & Ort. & Maks. & Min. & Ort. & Maks. \\
Yük talebi & 0,135 & 0,618 & 1,448 & 0,193 & 0,841 & 1,834 & 0,094 & 0,194 & 0,339 \\
PV güç üretimi & 0,208 & 0,377 & 0,766 & 0,421 & 0,677 & 1,350 & 0,100 & 0,130 & 0,173 \\
\hline
\end{tabular}

Uzam-zamansal yöntem ile elde edilen yük talebi ve PV güç üretimi tahminlerinin, önerilen yaklaşıma ait olan eşitlikler (1)-(30) içerisinde giriş verisi olarak kullanılmasıyla birinci ve ikinci durumda gerçekleşen güç alışverişleri sırasıyla Şekil 7 ve Şekil 8'de gösterilmektedir. Şekil 7'den görülebileceği üzere evler öncelikle kendi PV panelleri ile ürettikleri enerjiyi kullanmaktadırlar. Üretilen enerjisinin yetersiz olması durumunda ise diğer evlere ait ihtiyaç fazlası üretim kullanılmaktadır. Evlere ait üretimin olmadığı akşam saatlerinde ve toplam üretimin yetersiz kaldığ 1 saatlerde ise gerekli enerji şebekeden çekilmektedir. Bir paylaşımlı enerji depolama sisteminin kullanıldığı Durum-2'deki güç alışverişlerini gösteren Şekil 8'den anlaşılabileceği üzere bu durumda evler ihtiyaç fazlası enerjilerini satmak yerine depolayabilmekte ve böylece enerjinin birim fiyatının yüksek olduğu zamanlarda depolanmış olan enerjiyi kullanarak maddi bir fayda elde edebilmektedirler. Durum-1 ve Durum-2 için evler ile şebeke arasında gerçekleşen toplam enerji alışverişinin yer aldığı Şekil 9, bahsedilen enerjinin depolanması ve talep cevabı süresince kullanılmasını daha açı bir şekilde göstermektedir.

Şekiller 7-9'da görülen toplam maliyetteki azalma miktarları Çizelge 3’te verilmektedir. Görülebileceği üzere bir paylaşımlı depolama sisteminin ve enerji alışverişleri için bir enerji kredisi kazanma yönteminin kullanılması sonucunda evler fazla enerjilerini çoğunlukla depoladıklarından evlerin şebeke ile ve kendi aralarında yaptıkları enerji alışverişlerinin miktarı azalmıştır. Depolanan enerjinin pik yük zamanlarında kullanılması sonucunda ise toplam maliyet Durum-2'de önemli oranda düşürülebilmiş̧ir.

Paylaşımlı depolama sisteminin faydalarını daha ayrıntılı bir şekilde inceleyebilmek amacıyla dikkate alınan bir günlük süre boyunca sistemin evler ve şebeke ile enerji alışverişleri Şekil 10'da gösterilmektedir. Şekil 10'dan görülebileceği üzere talep cevabı etkinliği öncesinde paylaşımlı batarya evlerden gelen ihtiyaç fazlası enerji ile şarj olmaktadır ve etkinliğin başladığı andan itibaren evler kendilerine ait olan enerji kredilerini kullanarak bu süre boyunca yüksek fiyatı enerji alımlarını azaltmaktadırlar. Paylaşımlı batarya aynı zamanda sistem işletmecisine işletimsel ve ekonomik faydalar sağlamak amacıyla gerekmesi durumunda şebeke ile de enerji alı̧verişi yapmaktadır. Ayrıca, yine Şekil 10'dan görülebileceği üzere önerilen optimizasyon algoritması, evlerin talep cevabı etkinliği süresince kullanabileceği toplam enerji kredisi miktarını garanti edebilmek amacıyla etkinlik öncesinde enerji fiyatının düşük olduğu zamanlarda şebekeden enerji çekerek bataryanın şarj olmasını sağlayabilmektedir.

Son olarak, paylaşımlı bataryanın şebeke ve evler ile yaptığı enerji alışverişleri sonucunda bataryanın enerji durumunda meydana gelen değişimler ve evlerin kazandıkları/harcadıkları toplam enerji kredisi miktarları Şekil 11'de gösterilmektedir. Şekil 11'den görülebileceği üzere talep cevabı etkinliği öncesinde evlerin paylaşımlı bataryaya sağladığı enerji ile birlikte bataryanın SOE değeri artmakta ve evler enerji kredileri kazanmaktadırlar. Talep cevabı etkinliğinin başlaması ile birlikte ise evlerin kendilerine ait olan enerji kredileri; güç ihtiyaçları, kazanılmış kredi miktarları ve enerjinin saatlik fiyatı dikkate alınarak harcanmaktadır ve enerji deşarjı nedeniyle SOE değeri etkinlik süresi içerisinde minimum değerine inmektedir.

İlk iki durum için gerçekleştirilen benzetim çalışmalarında talep cevabı etkinliği için elektrik birim fiyatının en yüksek olduğu 18.00-22.00 saatleri arası seçilmiş̧ir. Belirtilen saatler arasında paylaşımlı depolama sisteminin farklı evler tarafından hangi saatler arasında ne oranda kullanılacağı ise önerilen enerji kredisi tabanlı optimizasyon algoritması tarafindan belirlenmektedir. Ancak belirtilen saat aralığının değiş̧tirilmesi ile farklı sonuçların elde edilebileceği açıktır. Literatürdeki çalışmalarda genellikle elektriğin birim fiyatına göre seçilmiş olan dört saatlik bir zaman aralığı benzetim çalışmasının gerçekleştirildiği süre boyunca sabit tutulmaktadır. Bazı çalışmalarda ise farklı mevsimler ve/veya haftanın farklı günleri için ayrı ayrı saat aralıkları belirlenerek elde edilebilecek faydaların 
arttırılması hedeflenmiştir. Bu çalışmalarda göz önüne alınan zaman aralıkları çoğunlukla varsayımlara ve eldeki veriden edinilen geçmiş tecrübelere dayanmaktadır. Ancak, herhangi bir gün için PV üretim değerlerinde ve/veya tüketim değerlerinde yaşanabilecek olan beklenmedik değişimlerin etkileri dikkate alınmamaktadır. Bu çalışmada ise önerilen tahmin yönteminin, gerçek uygulamalar için veri sağlamanın yanı sıra talep cevabı etkinliğinin başlangıç ve bitiş saatlerini belirlemede de kullanılabileceği öngörülmektedir.

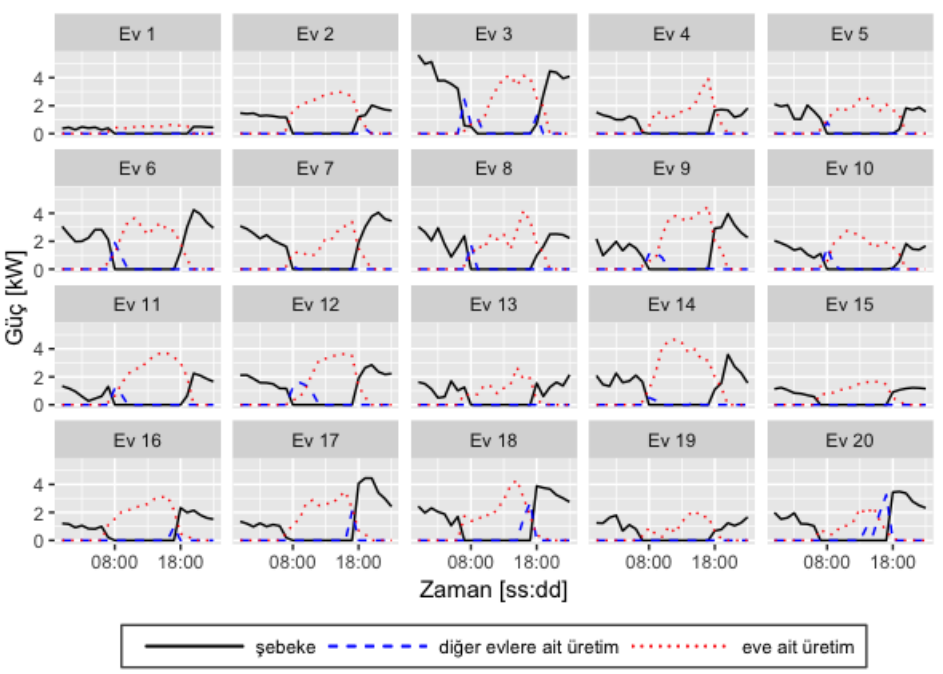

Şekil 7. Seçilen gün için Durum 1'de gerçekleşen güç değişimleri.

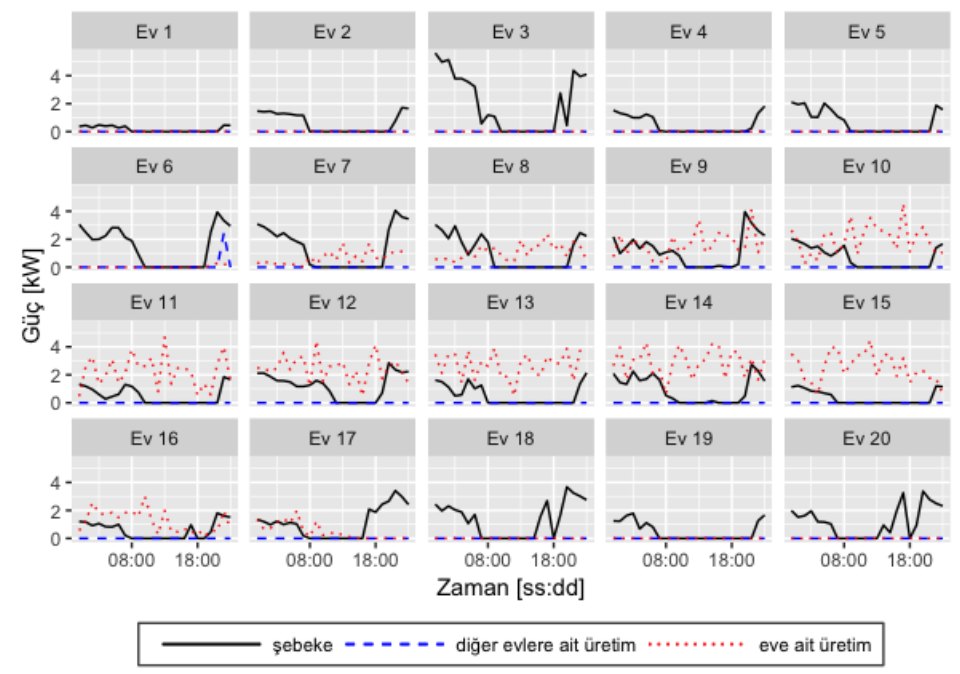

Şekil 8. Seçilen gün için Durum 2'de gerçekleşen güç değişimleri.

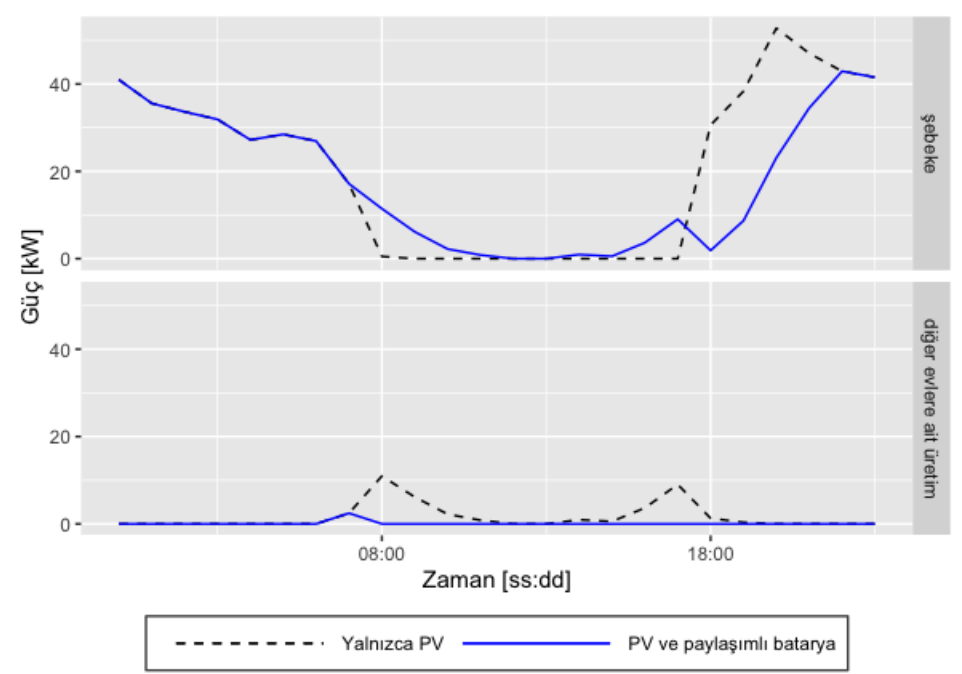

Şekil 9. Seçilen gün için Durum-1 ve Durum-2'de evler ile şebeke arasında gerçekleşen güç alışverişleri. 


\begin{tabular}{c|cccc}
\hline & $\begin{array}{c}\text { Şebekeden alınan } \\
{[\boldsymbol{k W}]}\end{array}$ & $\begin{array}{c}\text { Şebekeye satılan } \\
{[\boldsymbol{k W}]}\end{array}$ & $\begin{array}{c}\text { Evler arasinda kullanilan } \\
{[\boldsymbol{k W}]}\end{array}$ & $\begin{array}{c}\text { Toplam maliyet } \\
{[\boldsymbol{T L}]}\end{array}$ \\
\hline Yalnızca PV & 495,55 & 375,69 & 38,40 & 19,01 \\
PV ve batarya & 429,33 & 309,47 & 2,44 & 14,25 \\
\hline
\end{tabular}

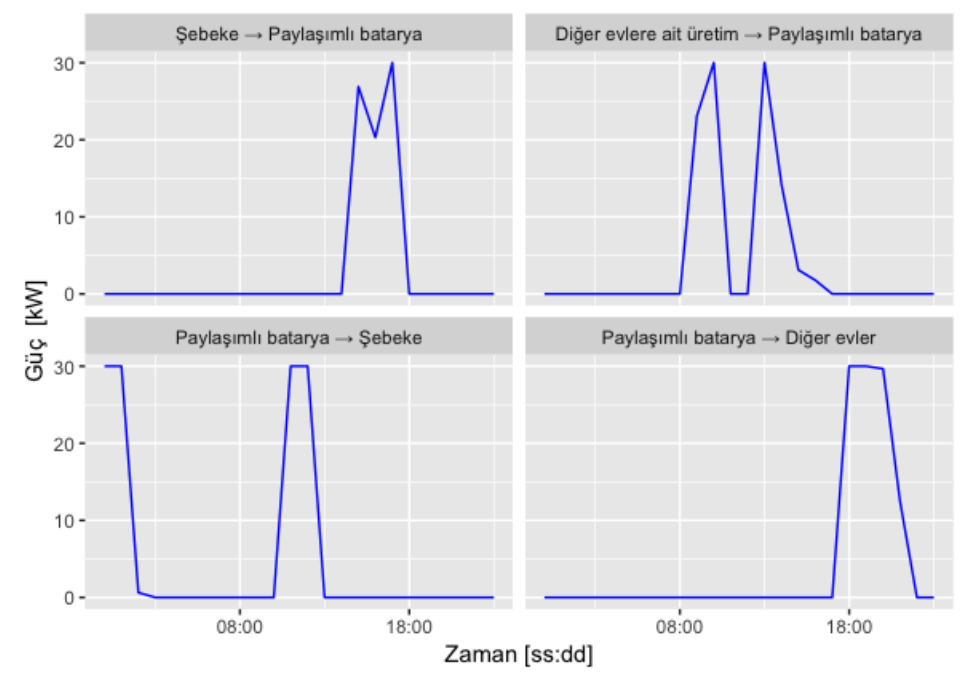

Şekil 10. Seçilen gün için Durum-2'de gerçekleşen paylaşımlı bataryaya ait güç alışverişleri.

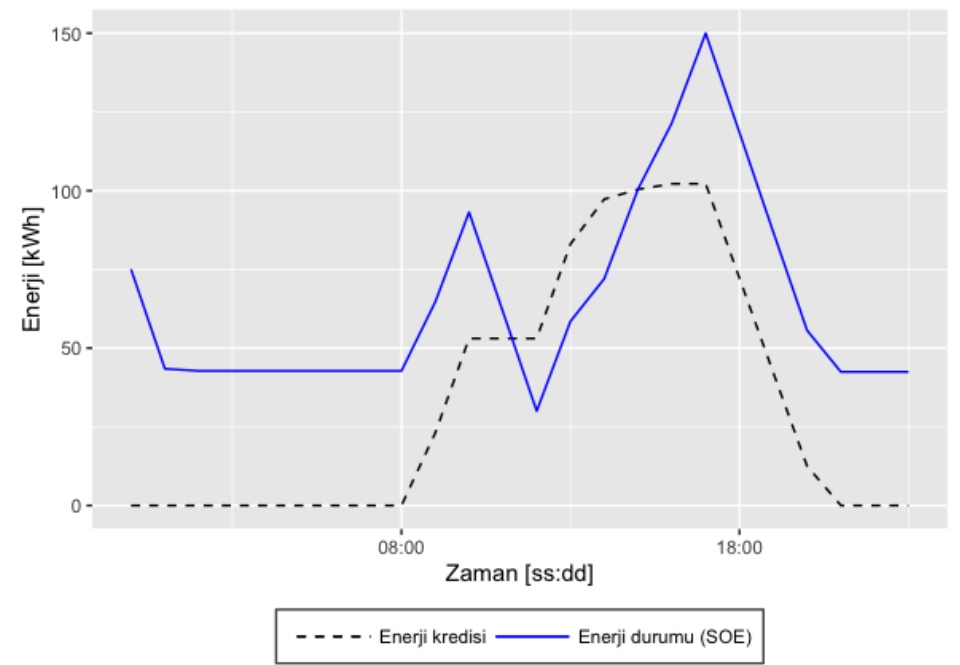

Şekil 11. Seçilen gün için Durum-2'de gerçekleşen batarya SOE ve enerji kredisi değişimleri.

Benzetim çalışmalarında yük taleplerine ve PV ünitelere ait tahminler saatlik olarak gerçekleştirilmiştir, ancak talep cevabı etkinliğinin gerçekleştirileceği zaman aralığını belirlemede daha yüksek çözünürlüğe ve doğruluğa sahip tahminlerin daha kesin sonuçlar vereceği düşünülmektedir. Bu amaçla, öncelikle eldeki veri kullanılarak on beş dakikalık veriler elde edilmiştir. Daha sonra ise bu verilerin yardımıyla 18.00-24.00 saatleri arasındaki her bir on beş dakika için PV üretimi ve yük talebi tahminleri gerçekleştirilmiştir. Bir günün tamamı yerine sadece bahsedilen aralık için tahminlerin gerçekleştirilmesinin sebebi, yukarıda bahsedildiği gibi 24 tahmin adımından daha fazlası için istatistiksel yöntemlerle yüksek doğrulukta tahminler yapılabilmesinin genellikle mümkün olmamasıdır. Tahminlerin başlangıç saati olarak 18.00'ın seçilmesinin nedeni ise PV üretiminin bu saat sonrasında oldukça azalmaya başlaması ve yük talebinin ise tam tersine artmaya başlamasıdır.

Üçüncü durumda gerçekleştirilen benzetim çalışmalarında, evlerin talep cevabı etkinliği içerisinde şebekeden çektiği toplam gücü minimize eden bir amaç fonksiyonu (Eşitlik (33)) kullanılmıştır. Yeni bir amaç fonksiyonu tanımlamasının sebebi, bu durumda temel hedefin tüketicilere ait toplam maliyeti azaltmak yerine pik talep gücünü azaltmak olarak seçilmesidir. Böylece paylaşımlı bataryaların bir diğer önemli faydası olan sistem işletmecilerine gerekli zamanlarda destek olabilme potansiyeli de incelenebilmiştir.

$$
T T G A=\sum_{e} \sum_{z}\left(P_{e, z}^{\text {alinan }, S}\right), \forall e, z \in\left[Z^{\text {DR_baslangic }}, Z^{D R_{-} \text {bitis }}\right]
$$

Belirtilen zaman aralığı için yük taleplerine ve PV ünitelere ait tahminler gerçekleştirildikten sonra önerilen yöntem öncelikle saat 18.00'a kadar saatlik tahminler ile çalıştırılmıştır ve sonrasında ise kalan süre için on beşer dakikalık tahminler kullanılmıştır. Elde 
edilen on beş dakikalık tahminlerin doğruluğuna ait hata ölçütleri Çizelge 4'te verilmektedir. Daha sonra, tahmin değerlerinin dikkate alınmasıyla toplamda en yüksek güç değerlerine sahip olan aralık 19.45-23.45 olarak belirlenmiştir ve benzetim çalışmalarında talep cevabı etkinliğinin başlangıç ve çıkış saatleri bu saatler olarak seçilmiştir.

Şekil 12'de paylaşımlı bataryanın mevcut olmadığı, paylaşımlı bataryanın mevcut olduğu ve bir saatlik tahminler ile talep cevabı etkinliğinin 18.00-22.00 arasında gerçekleştirildiği ve son olarak paylaşımlı depolama ünitesinin mevcut olduğu ve talep cevabı etkinliğinin on beş dakikalık tahminler ile 19.45-23.45 arasında gerçekleştirildiği üç farklı yaklaşım göz önüne alınmıştır. Şekil 12'den görülebileceği üzere; on beş dakikalık tahminler yardımıyla talep cevabı etkinliğinin zaman aralığını belirlemek, sistem işletmecisine pik yük kontrolünde daha fazla ve daha uzun süreli bir destek sağlamaktadır. Saatlik tahminlerin kullanıldığı ve sabit talep cevabı etkinliği zamanının kullanıldığı durumda ise seçilen zaman aralığından dolayı saat 22.00 sonrasında yeni bir pik yük ortaya çıkmaktadır.

Son olarak, bu çalışmada kullanılan ve MATLAB ortamında modellenen tahmin yaklaşımının bir saatlik ve 24 adımlık tahminleri evlerin tamamı için 13 saniyede, 15 dakikalık ve 24 adımlık tahminleri ise 18 saniyede gerçekleştirdiği belirtilmelidir. Önerilen optimizasyon algoritmasının çözümü içinse General Algebraic Modelling System (GAMS) programı ve CPLEX çözücüsü kullanılmıştır ve sonuçlar ihmal edilebilecek kadar kısa bir sürede (yaklaşık 1 saniye) elde edilmiştir.

Çizelge 4. 15 Dakikalık Tahmin Değerlerine Ait Farklı Hata Ölçütü Değerleri

\begin{tabular}{l|ccccccccc}
\hline & \multicolumn{4}{|c}{ MAE $[\boldsymbol{k W}]$} & \multicolumn{4}{c}{$\boldsymbol{R M S E}[\boldsymbol{k W}]$} & \multicolumn{3}{c}{ NRMSE [\%] } \\
\hline & Min. & Ort. & Maks. & Min. & Ort. & Maks. & Min. & Ort. & Maks. \\
Yük talebi & 0,193 & 0,852 & 1,549 & 0,246 & 1,119 & 2,494 & 0,142 & 0,271 & 0,441 \\
PV güç üretimi & 0,061 & 0,121 & 0,197 & 0,134 & 0,245 & 0,400 & 0,073 & 0,165 & 0,325 \\
\hline
\end{tabular}

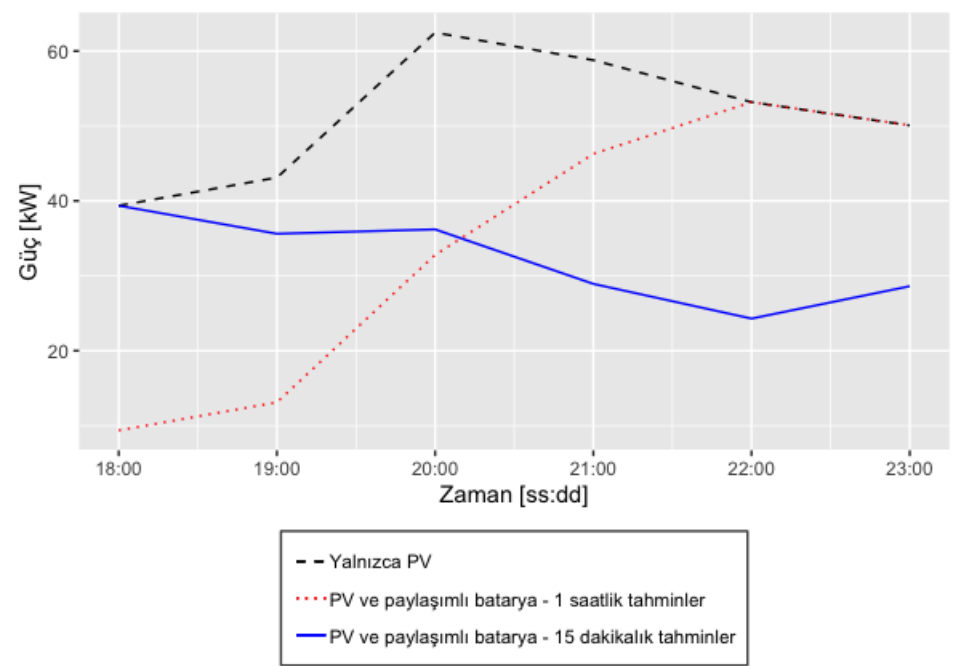

Şekil 12. Talep cevabı etkinliği süresince Durum-3’te evler ile şebeke arasında gerçekleşen güç alışverişleri.

\section{Sonuçlar}

$\mathrm{Bu}$ çalışmada, paylaşımlı bataryaların tüketicilere ve sistem işletmecilerine sağlayabilecekleri faydaları değerlendirebilmek amacıyla yük talebi ve PV güç üretimi tahminlerine dayanan bir enerji yönetimi algoritması geliştirilmiştir. Önerilen yöntemin etkinliğini değerlendirebilmek amacıyla her biri PV ünitelere sahip olan ve aynı bölgede bulunan belirli bir sayıdaki evsel tüketici göz önüne alınmıştır. Önerilen yaklaşımın temel hedefi, bahsedilen tahminlerden faydalanarak, özellikle enerji fiyatının yüksek olduğu zamanlarda evsel tüketicilerin şebekeden çektiği enerji miktarını sınırlandıracak şekilde evlerin paylaşımlı batarya ile ve kendi aralarındaki enerji alışverişlerini en ekonomik şekilde sağlamaktır. Bu amaçla, ilgili enerji alışverişleri sonucunda tüketicilerin enerji kredileri kazandıkları ve bu kredileri bir talep cevabı etkinliği süresi içerisinde harcadıkları varsayılmıştır. Gerçekleştirilen benzetim çalışmalarında 20 adet evden oluşan bir ağ için paylaşımlı depolama ünitesinin kullanılmasının toplam maliyeti \%25,04 azalttığı gözlemlenmiştir. Son olarak, talep cevabı etkinliklerinde başlangıç ve bitiş saatlerinin en yüksek oranda fayda sağlayacak şekilde belirlenebilmesi amacıyla farklı zaman adımlarında tahminlerin önerilen enerji yönetimi algoritmasına dahil edilmesiyle, paylaşımlı bataryalardan elde edilebilecek faydalarının arttırılabilmesi sağlanmıştır. Bu durumda ise paylaşımlı depolama ünitesinin, şebekedeki evlerden kaynaklanan pik yük talebini, depolama ünitesinin var olmadığı duruma göre \%37,13 ve depolama ünitesinin var olduğu ancak talep cevabı etkinliğinin süresinin kısa süreli tahminler ile belirlenmediği duruma göre \%5,76 azalttığı görülmüştür. Daha önemlisi, gün içerisinde görülen en yüksek güç talebi değeri, depolama ünitesinin var olmadığı duruma göre \%36,98, talep cevabı etkinliğinin süresinin belirlenmediği duruma göre $\% 25,98$ azalmıştır.

$\mathrm{Bu}$ çalışmada belirtilen sonuçlar, sınırlı sayıda evsel yük ve yalnızca bir adet paylaşımlı depolama ünitesi kullanılarak elde edilmiştir. Birden fazla sayıda paylaşımlı depolama ünitesi içeren daha geniş bir dağıtım ağının dikkate alınabileceği farklı çalışmalarda, artacak tüketici sayısı ve çeşitliliği (endüstriyel, ticari, vb.) ile birlikte sağlanabilecek faydaların kayda değer derecede artacağı ifade edilebilir. Bu çalışmalarda ayrıca batarya tabanlı paylaşımlı depolama üniteleri yerine kullanılabilecek daha yüksek kapasitelere sahip enerji depolama teknolojilerinin teknik ve ekonomik faydaları da incelenebilir. Ayrıca, paylaşımlı depolama ünitelerinin sanal güç e-ISSN: 2148-2683 
santralleri (virtual power plants) yapısı içerisinde kullanılması durumunda elde edilebilecek ekonomik faydalar da ayrı bir çalışmanın konusu olarak ele alınabilir.

\section{Teșekkür}

Bu çalışma 117E527 No'lu proje kapsamında Türkiye Bilimsel ve Teknolojik Araştırma Kurumu (TÜBİTAK) tarafından desteklenmektedir.

\section{Referanslar}

[1] Imani, M. H., Ghadi, M. J., Ghavidel, S., \& Li, L. (2018). Demand response modeling in microgrid operation: a review and application for incentive-based and time-based programs. Renewable and Sustainable Energy Reviews, 94, 486-499.

[2] Erdinc, O., Taşcikaraoğlu, A., Paterakis, N. G., \& Catalão, J. P. (2018). Novel incentive mechanism for end-users enrolled in DLCbased demand response programs within stochastic planning context. IEEE Transactions on Industrial Electronics, 66(2), 14761487.

[3] Morstyn, T., Hredzak, B., \& Agelidis, V. G. (2016). Control strategies for microgrids with distributed energy storage systems: An overview. IEEE Transactions on Smart Grid, 9(4), 3652-3666.

[4] Erdinç, O., Taşcıkaraoğlu, A., Paterakis, N. G., Dursun, I., Sinim, M. C., \& Catalão, J. P. (2017). Comprehensive optimization model for sizing and siting of DG units, EV charging stations, and energy storage systems. IEEE Transactions on Smart Grid, 9(4), 38713882.

[5] Nghitevelekwa, K., \& Bansal, R. C. (2018). A review of generation dispatch with large-scale photovoltaic systems. Renewable and sustainable energy reviews, 81, 615-624.

[6] Paterakis, N. G., Taşcıkaraoğlu, A., Erdinc, O., Bakirtzis, A. G., \& Catalão, J. P. (2016). Assessment of demand-response-driven load pattern elasticity using a combined approach for smart households. IEEE Transactions on Industrial Informatics, 12(4), 15291539.

[7] Siano, P., \& Sarno, D. (2016). Assessing the benefits of residential demand response in a real time distribution energy market. Applied Energy, 161, 533-551.

[8] Taşcıkaraoğlu, A., Paterakis, N.G., Erdinç, O. and Catalao, J.P., 2019. Combining the flexibility from shared energy storage systems and DLC-based demand response of HVAC units for distribution system operation enhancement. IEEE Transactions on Sustainable Energy, 10(1), pp.137-148.

[9] Taşcıkaraoğlu, A. (2018). Economic and operational benefits of energy storage sharing for a neighborhood of prosumers in a dynamic pricing environment. Sustainable cities and society, 38, 219-229.

[10] Muratori, M., \& Rizzoni, G. (2015). Residential demand response: Dynamic energy management and time-varying electricity pricing. IEEE Transactions on Power systems, 31(2), 1108-1117.

[11] Nan, S., Zhou, M., \& Li, G. (2018). Optimal residential community demand response scheduling in smart grid. Applied Energy, 210, 1280-1289.

[12] Hu, Q., Li, F., Fang, X., \& Bai, L. (2016). A framework of residential demand aggregation with financial incentives. IEEE Transactions on Smart Grid, 9(1), 497-505.

[13] Asadinejad, A., Rahimpour, A., Tomsovic, K., Qi, H., \& Chen, C. F. (2018). Evaluation of residential customer elasticity for incentive based demand response programs. Electric Power Systems Research, 158, 26-36.

[14] Haider, H. T., See, O. H., \& Elmenreich, W. (2016). A review of residential demand response of smart grid. Renewable and Sustainable Energy Reviews, 59, 166-178.

[15] Yan, X., Ozturk, Y., Hu, Z., \& Song, Y. (2018). A review on price-driven residential demand response. Renewable and Sustainable Energy Reviews, 96, 411-419.

[16] Lu, Q., Yu, H., Zhao, K., Leng, Y., Hou, J., \& Xie, P. (2019). Residential demand response considering distributed PV consumption: A model based on China's PV policy. Energy, 172, 443-456.

[17] Venizelou, V., Philippou, N., Hadjipanayi, M., Makrides, G., Efthymiou, V., \& Georghiou, G. E. (2018). Development of a novel time-of-use tariff algorithm for residential prosumer price-based demand side management. Energy, 142, 633-646.

[18] Iria, J., Soares, F., \& Matos, M. (2018). Optimal supply and demand bidding strategy for an aggregator of small prosumers. Applied Energy, 213, 658-669.

[19] Li, R., Wang, W., Wu, X., Tang, F., \& Chen, Z. (2019). Cooperative planning model of renewable energy sources and energy storage units in active distribution systems: A bi-level model and Pareto analysis. Energy, 168, 30-42.

[20] Shakeri, M., Shayestegan, M., Reza, S. S., Yahya, I., Bais, B., Akhtaruzzaman, M., ... \& Amin, N. (2018). Implementation of a novel home energy management system (HEMS) architecture with solar photovoltaic system as supplementary source. Renewable energy, 125, 108-120. 
[21] Wang, G., Zhang, Q., Li, H., McLellan, B. C., Chen, S., Li, Y., \& Tian, Y. (2017). Study on the promotion impact of demand response on distributed PV penetration by using non-cooperative game theoretical analysis. Applied energy, 185, 1869-1878.

[22] Sivaneasan, B., Kandasamy, N. K., Lim, M. L., \& Goh, K. P. (2018). A new demand response algorithm for solar PV intermittency management. Applied energy, 218, 36-45.

[23] Bashir, A., Pourakbari Kasmaei, M., Safdarian, A., \& Lehtonen, M. (2018). Matching of local load with on-site PV production in a grid-connected residential building. Energies, 11(9), 2409.

[24] O'Shaughnessy, E., Cutler, D., Ardani, K., \& Margolis, R. (2018). Solar plus: A review of the end-user economics of solar PV integration with storage and load control in residential buildings. Applied energy, 228, 2165-2175.

[25] Sardi, J., Mithulananthan, N., \& Hung, D. Q. (2017). Strategic allocation of community energy storage in a residential system with rooftop PV units. Applied energy, 206, 159-171.

[26] Wang, Z., Gu, C., \& Li, F. (2018). Flexible operation of shared energy storage at households to facilitate PV penetration. Renewable energy, 116, 438-446.

[27] Gomez-Herrera, J. A., \& Anjos, M. F. (2018). Optimal collaborative demand-response planner for smart residential buildings. Energy, 161, 370-380.

[28] Notton, G., Nivet, M. L., Voyant, C., Paoli, C., Darras, C., Motte, F., \& Fouilloy, A. (2018). Intermittent and stochastic character of renewable energy sources: Consequences, cost of intermittence and benefit of forecasting. Renewable and Sustainable Energy Reviews, 87, 96-105.

[29] Tascikaraoglu, A. (2018). Evaluation of spatio-temporal forecasting methods in various smart city applications. Renewable and Sustainable Energy Reviews, 82, 424-435.

[30] Córdova, S., Rudnick, H., Lorca, A., \& Martínez, V. (2018). An Efficient Forecasting-Optimization Scheme for the Intraday Unit Commitment Process Under Significant Wind and Solar Power. IEEE Transactions on Sustainable Energy, 9(4), 1899-1909.

[31] Tascikaraoglu, A., \& Sanandaji, B. M. (2016). Short-term residential electric load forecasting: A compressive spatio-temporal approach. Energy and Buildings, 111, 380-392.

[32] Huang, P., \& Sun, Y. (2019). A robust control of nZEBs for performance optimization at cluster level under demand prediction uncertainty. Renewable Energy, 134, 215-227.

[33] Mediwaththe, C. P., Shaw, M., Halgamuge, S. K., Smith, D., \& Scott, P. M. (2019). An Incentive-compatible Energy Trading Framework for Neighborhood Area Networks with Shared Energy Storage. IEEE Transactions on Sustainable Energy.

[34] Liu, J., Zhang, N., Kang, C., Kirschen, D. S., \& Xia, Q. (2018). Decision-Making models for the participants in cloud energy storage. IEEE Transactions on Smart Grid, 9(6), 5512-5521.

[35] Sanandaji, B. M., Tascikaraoglu, A., Poolla, K., \& Varaiya, P. (2015, July). Low-dimensional models in spatio-temporal wind speed forecasting. In 2015 American Control Conference (ACC) (pp. 4485-4490). IEEE.

[36] Pecan Street, Inc. Pecan Street Dataport 2017. <https://dataport.pecanstreet.org>.

[37] ComEd, https://hourlypricing.comed.com/live-prices/predicted-prices/. 